\title{
6. Options for governance, institutional arrangements and private and public decision- making across scales and sectors
}

Lead authors: Charlotta Söderberg, Monica Hammer. Co-authors: Marie Kvarnström, Kristin Magnussen, Tero Mustonen, Milla Mäenpää, Michael Køie Poulsen, Eva Roth, Jan Sörensen, Håkan Tunón, Susanne Vävare.

\section{Box 13: Summary}

This chapter examines the conceptual framework boxes and fluxes on "Institutions and governance and other indirect drivers" (Ch. 1, Fig. 1). International and EU governance of relevance for ecosystem services, biodiversity and water is presented. Policy integration, policy coherence, management regimes and stakeholder involvement is reflected upon. The chapter contributes to further understanding of the current and future challenges for sustainable use and conservation of biodiversity and ecosystem services. It provides insights in options for integrating biodiversity and ecosystem services into sustainable development strategies and provides examples of current policy conflicts, along with trade-offs and innovative governance strategies for management of natural resources. Policy-makers need to find ways to handle policy conflicts, improve integration of different stakeholders' perspectives and value dimensions including ILK in policymaking, develop new data collection methods for linking biodiversity and ecosystem services, and develop governance systems that enhance transparency, sustainability and human well-being.

\subsection{Introduction}

The main role of this chapter is to reflect the conceptual framework boxes and fluxes on "Institutions and governance and other indirect drivers" (Chapter 1, Figure 1). Our aim is to provide insight into the relationship between international, EU and Nordic governance structures and give examples of how they affect important aspects of democracy and socio-ecological trade-offs in the Nordic coastal regions. In order to do so, we have chosen to focus mainly on the formal systems for water governance in the different countries. The implementation of the EU Water Framework Directive (WFD) (where relevant) or formal systems for water governance (where the WFD is not relevant) is presented to obtain a comparative overview of the formal institutional frameworks for the governance of natural resources. This chapter examines how biodiversity and ecosystem services are mainstreamed in practical policy in the Nordic 
coastal regions and presents the different international and national policies of relevance when working towards the goal of achieving good water quality. Water quality is defined by both ecological and chemical parameters, which in turn is affected by a range of actions both on land and on water in coastal regions, and thus depends on decisions in many different policy areas. Therefore, water governance is a policy area signified by the need to handle goal-conflicts (Söderberg, 2016) and our focus on water governance provides highly relevant insights into institutions for biodiversity and ecosystem services governance, how different policies interact and how trade-offs between different ecosystem services are handled in the Nordic region.

International and EU governance of relevance for ecosystem services, biodiversity and water governance is briefly presented. Institutions for water governance in the different countries are mapped out and compared and examples from case studies are provided. Policy integration, policy coherence, management regimes and stakeholder involvement is reflected upon. Through this approach, the chapter will contribute to further understanding of the current and future challenges for sustainable use and conservation of biodiversity and ecosystem services, provide insights in options for integrating biodiversity and ecosystem services into sustainable development strategies, and provide examples of current policy conflicts and innovative governance strategies for the management of natural resources. Based on the overview in this chapter and our case studies, this chapter presents opportunities and challenges for policy- and decision-making in the Nordic region, identifies knowledge gaps and provides recommendations for the future.

\subsection{Framing institutions and policy options for biodiversity and ecosystems governance}

Environmental issues have been on the international agenda since the conservation movement arose in the early zoth century and were first discussed within the UN in the early 1970s. The 1972 United Nations Conference on the Human Environment (UNCHE) in Stockholm recognised the human responsibility to take the environment into consideration and the need to conserve natural resources for present and future generations. Fifteen years later, the Brundtland Commission's Our common future (WCED, 1987) defined sustainable development as: "development that meets the needs of the present without compromising the ability of future generations to meet their own needs" (WCED, 1987, p. 43) and emphasised that we must change policies and institutions if we wish to address the challenges of interlocked economic and ecological systems. As a result, the principle of environmental policy integration (EPI) was included under Article 8 in Agenda 21, which was the outcome of the 1992 UN Conference on Environment and Development (UNCED) in Rio de Janeiro. Persson (2004, p. 1) defines EPI as "the integration of environmental aspects and policy objectives into sector policies". The concept of sustainable development is the basis and the target of environmental policy integration, which after the Rio Declaration, has become increasingly explicit in international and European policy. The principle of environmental policy integration also 
has a long history within the EU and Article 11 of the Treaty of the European Union prescribes that environmental concerns are to be integrated into other policy areas (European Union 2016, Article 11). EU environmental policy also prescribes the precautionary principle, to prevent pollution and rectifying pollution at the source, as well as maintaining a high level of environmental protection and the principle that the polluter pays (European Union, 2016, Article 191-193). Water and biodiversity protection is governed at international and EU-level by a number of treaties, agreements and directives. Efforts to limit and reduce emissions into air and water have a long history. Several international agreements have been adopted in recent decades with the aim of limiting emissions of pollutants. The Nordic EU countries Denmark, Sweden and Finland are known as "Green Member States" within the EU - recognized as environmental forerunners (Liefferink and Skou Andersen, 2010). There is also a common Nordic culture of well-developed information-systems, equity, trust in the State and obedience to regulations, as well as a long-standing corporate governance tradition where participatory governance structures and extensive cross-border cooperation has a long history (OECD, 2003; Lekvall, 2014; Moos Nihlfors, Merok Paulsen, 2016). All of the above make the Nordic countries relevant to study and compare from an environmental policy implementation perspective. What are the trends, the lessons and the obstacles for integrating biodiversity in the Nordic?

In order to improve the sustainability of biodiversity and ecosystem services, the impact of institutions and governance needs to be understood, as is emphasised in the IPBES framework (Diaz et al., 2015; Pascual et al., 2017). The interaction between public and private actors is determined by the formal societal institutions or "rules on paper" (e.g. policies and laws) and informal institutions in society or rules in use (e.g. social norms and traditions) (Ostrom, 1990; North, 1990). This chapter maninly focuses on the formal institutions for environmental governance in the Nordic. It is important to consider that the general trend within environmental governance in the Nordic countries, is the move towards polycentric governance (Ostrom, 2010; Biggs, 2015) and participatory governance (Driessen, 2014; Sandström \& Söderberg, forthcoming; Duit \& Löf, 2009; Primmer, 2015), which means that many different actors are involved in the policy making process in more or less formal ways. Stakeholder participation in water governance and how the integration of ILK has been organized within the Nordic countries is presented in this report. A move towards multi-level governance (Bache \& Flinders, 2003; Joas \& Eckerberg, 2004) can also be observed, where power previously held by the nation state shifts both upwards (to the supranational level), downwards (to the local level) and sideways (to involvement of both private and public actors in policymaking). These trends have implications for policy coherence: since policy density is high, there are many different political goals to be achieved simultaneously, which increases the risk for policy conflicts. Such policy conflicts are often related to the difficulty in balancing ecological, economic and social sustainability, as well as to the difficult weighting of different ecological goals (Söderberg, 2016; Söderberg \& Eckerberg, 2013). Policy conflicts detected in our case studies in the Nordic region are also presented here. 


\subsection{International and EU governance}

A number of international conventions protecting ecosystem services and biodiversity have been integrated into different regulations and directives within the EU. An overview of the Multilateral Environmental Agreements relevant for the coastal regions in the Nordic countries can be found in Table 6. Important to mention are the Ramsar Convention on the conservation of wetlands (1971), the World Heritage Convention (1972), the CITES Convention on International Trade in Endangered Species (1973), the Bonn Convention on the protection of Migratory Species of Wild Fauna (1979), the Bern Convention of the protection of European Wildlife and natural Habitats (1982) and the UN Convention on Biological Diversity (CBD) (1992) requiring a more integrated ecosystem approach to environmental governance. The ecosystem approach in the CBD is defined as "a strategy for integrated management of land, water and living resources that promotes conservation and sustainable use in an equitable way". It also emphasizes the economic and social aspects of the human system and its principle two states that "management should be decentralized to the lowest appropriate level" (CBD, 2004a). The objectives of the CBD are the conservation of biological diversity, the sustainable use of its components and the fair and equitable sharing of the benefits arising out of the utilization of genetic resources. Several different instruments have been developed within CBD, one of which has focused on ILK and issues regarding full and effective participation in decision-making and sustainable customary use. The CBD has also agreed on a Strategic Plan for Biodiversity, including the Aichi Biodiversity Targets for the 20112020 period. The plan provides an overarching framework on biodiversity, not only for biodiversity-related conventions, but for the entire UN system and all other partners engaged in biodiversity management and policy development. Aichi Target 2 aims to, by 2020, achieve that "biodiversity values have been integrated into national and local development and poverty reduction strategies and planning processes and are being incorporated into national accounting, as appropriate, and reporting systems". Furthermore, Aichi target 18 states that ILK and "customary use of biological resources" should by 2020 be fully integrated and reflected in the implementation of CBD with "the full and effective participation of indigenous and local communities, at all relevant levels." Public participation in environmental decision-making and access to environmental information is also required under the Aarhus Convention (2005). Furthermore, the Paris Agreement (2015) aims to enhance the implementation of the United Nations Framework Convention on Climate Change (UNFCCC) through ambitious climate change mitigation and adaptation efforts, with the aim to keep a global temperature rise below 2 degrees Celsius. The Agreement can be expected to have implications for biodiversity and ecosystem management work in the Nordic region.

Two EU directives are of particular importance for biodiversity governance within the EU and thus important to mention here: the Birds Directive (Directive 2009/147/EC of the European Parliament and of the Council of 30 November 2009 on the conservation of wild birds) and the Habitats Directive (Council Directive 92/43/EEC of 21 May 1992 on the conservation of natural habitats and of wild fauna and flora). These two directives oblige member states to define Natura 2000 areas to protect biodiversity 
and conserve habitats and species. Biodiversity protection and ecosystem restoration is currently emphasised in the 2020 Biodiversity Strategy (European Commission, 2011) and the 7 th Environment Action Programme (European Union, 2013). Biodiversity protection should thus be integrated into policymaking in all EU member states.

The ecosystem approach concept as used by CBD has been taken up by e.g. the Regional Seas Conventions OSPAR, for the North East Atlantic and HELCOM for the Baltic Sea (CBD, 2004a, Hammer, 2015). The EU Marine Strategy Framework Directive (Directive 2008/56/EC of the European Parliament and of the Council of 17 June 2008 establishing a framework for community action in the field of marine environmental policy) uses the term "ecosystem based approach" and under the EU Common Fisheries Policy (CFP) both the terms "ecosystem approach" and "ecosystem-based approach" are used and seemingly in the same context (European Commission, 2009, 2011). These terms are thus used as synonyms in this chapter.

The two most important pieces of EU legislation on water governance are the WFD, (inland and coastal waters) adopted in 2000 (European Parliament, 2000) and the Marine Strategy Framework Directive (European Parliament, 2008). Both of these directives require member states to set and implement action plans in order to achieve the directives' objectives. The implementation of the WFD and water governance in the Nordic is discussed in more depth later in this chapter.

Water governance is closely related to spatial planning in landscapes and seascapes. The EU Commission has proposed a Framework for Marine Spatial Planning (MSP) and Integrated Coastal Zone Management (ICZM). The ultimate goal for marine planning is to identify the use of space at sea for various sea-based activities. The MSP aims to identify the different uses of marine space and facilitate a coherent and sustainable implementation of various initiatives for the marine environment. ICZM is a tool for all the political processes that affect the coastal zone with the goal of achieving sustainable development in the interaction between land and sea. MSP and ICZM complement each other, such as the Marine Directive, the Renewable Energy Directive, Oceans Highways Initiative, and the Habitats Directive, but also the reformed Common Fisheries Policy and the new Structural Funds. Under the proposed framework, each Member State is to establish and implement a development plan for the sea areas, along with an integrated strategy for the coastal zone, for which there are a number of minimum requirements. These plans and strategies should be revised every six years.

Several EU Directives also impact water management. Among the most important are the Floods Directive (2007/60 / EC), the Habitats Directive (1992/43 / EC), the Birds Directive (1979/409 / EEC), the Drinking Water Directive and the Nitrates Directive (91/676 / EEC), which contains minimum requirements for reducing nitrogen losses (nitrate losses) from agriculture to surface water, groundwater, and coastal and marine waters. The Nitrate Directive requires each member state to identify areas that are vulnerable to nitrate pollution and establish a program of measures aimed at reducing nutrient leaching from agriculture. The Common Fisheries Policy (CFP) and the Common Agricultural Policy (CAP) also have great influence on the environment in the coastal zone. In addition, the Emission Ceilings Directive for air emissions (2001/81 / EC) and the REACH chemicals legislation are important for water management. As 
directives, laws and actions in many different policy areas affect water quality, water management can be viewed as an illustrative case in order to illuminate the applied management of biodiversity and ecosystem services in the Nordic region.

Table 6: Selection of Multilateral Environmental Agreements (MEA) relevant for the coastal regions in the Nordic

\begin{tabular}{|c|c|c|c|c|}
\hline MEA & Purpose & Date adopted & $\begin{array}{l}\text { Entry into } \\
\text { force }\end{array}$ & $\begin{array}{l}\text { Parties in } \\
\text { total/Nordic }\end{array}$ \\
\hline $\begin{array}{l}\text { Ramsar Convention - } \\
\text { Convention on Wetlands of } \\
\text { International Importance } \\
\text { especially as Waterfowl } \\
\text { Habitat }\end{array}$ & $\begin{array}{l}\text { To conserve and promote the } \\
\text { wise use of wetlands }\end{array}$ & 1971 & 1975 & $169 / a l l$ \\
\hline $\begin{array}{l}\text { World Heritage Convention } \\
\text { - Convention concerning the } \\
\text { protection of the world } \\
\text { cultural and natural heritage }\end{array}$ & $\begin{array}{l}\text { To establish an effective system } \\
\text { of identification, protection and } \\
\text { preservation of cultural and } \\
\text { natural heritage, and to provide } \\
\text { emergency and long-term } \\
\text { protection of sites of value }\end{array}$ & 1972 & 1975 & 193/all \\
\hline EU Birds Directive & $\begin{array}{l}\text { Oldest EU legislation on } \\
\text { environment. Emphasis on the } \\
\text { protection of habitats for } \\
\text { endangered and migratory bird } \\
\text { species. It establishes a network } \\
\text { of Special Protection Areas } \\
\text { (SPAs) including all the most } \\
\text { suitable territories for these } \\
\text { species. Since 1994, all SPAs are } \\
\text { included in the Natura 2000 } \\
\text { ecological network. Overarching } \\
\text { strategy: EU Biodiversity } \\
\text { Strategy } 2020\end{array}$ & 1979 & $\begin{array}{l}\text { Amended in } \\
2009\end{array}$ & $\begin{array}{l}28 \text { EU Member } \\
\text { states }\end{array}$ \\
\hline $\begin{array}{l}\text { CMS - Convention on the } \\
\text { Conservation of Migratory } \\
\text { Species of Wild Animals }\end{array}$ & $\begin{array}{l}\text { To conserve wild animal species } \\
\text { that migrate across or outside } \\
\text { national boundaries by } \\
\text { developing species-specific } \\
\text { agreements, providing protection } \\
\text { for endangered species, } \\
\text { conserving habitat, and } \\
\text { undertaking cooperative research }\end{array}$ & 1979 & 1983 & $\begin{array}{l}124 \text { /Sweden, } \\
\text { Finland, } \\
\text { Denmark, } \\
\text { Norway }\end{array}$ \\
\hline $\begin{array}{l}\text { CBD - Convention on } \\
\text { Biological Diversity }\end{array}$ & $\begin{array}{l}\text { To conserve biological diversity } \\
\text { and promote its sustainable use, } \\
\text { and to encourage the equitable } \\
\text { sharing of the benefits arising out } \\
\text { of the utilization of genetic } \\
\text { resources. Ecosystem approach. } \\
\text { Strategic Plan for Biodiversity } \\
\text { 2010-2020, including Aichi } \\
\text { Biodiversity Targets }\end{array}$ & 1992 & 1993 & 196 /all Nordic \\
\hline
\end{tabular}

\footnotetext{
${ }^{20} \mathrm{http}: / /$ ec.europa.eu/environment/nature/natura200o/index_en.htm
} 


\begin{tabular}{|c|c|c|c|c|}
\hline MEA & Purpose & Date adopted & $\begin{array}{l}\text { Entry into } \\
\text { force }\end{array}$ & $\begin{array}{l}\text { Parties in } \\
\text { total/Nordic }\end{array}$ \\
\hline $\begin{array}{l}\text { Aarhus Convention - } \\
\text { Convention on Access to } \\
\text { Information, Public } \\
\text { Participation in Decision- } \\
\text { Making } \\
\text { Access to Justice in } \\
\text { Environmental Matters }\end{array}$ & $\begin{array}{l}\text { To guarantee the rights of access } \\
\text { to information, public } \\
\text { participation in decision-making, } \\
\text { and legal redress in } \\
\text { environmental matters }\end{array}$ & 1998 & 2001 & $\begin{array}{l}47 \text { /Sweden, } \\
\text { Norway, } \\
\text { Finland, } \\
\text { Iceland, } \\
\text { Denmark }\end{array}$ \\
\hline $\begin{array}{l}\text { EU Water Framework } \\
\text { Directive }\end{array}$ & $\begin{array}{l}\text { To achieve good ecological status } \\
\text { in all inland and coastal waters }\end{array}$ & 2000 & 2000 & $\begin{array}{l}28 \text { EU Member } \\
\text { States/Nor- } \\
\text { way \& Iceland }\end{array}$ \\
\hline EU Habitat Directive & $\begin{array}{l}\text { Conservation of natural habitats } \\
\text { and wild fauna and flora to } \\
\text { promote the maintenance of } \\
\text { biodiversity, taking account of } \\
\text { economic, social, cultural and } \\
\text { regional requirements, including } \\
\text { Natura } 2000 \text { ecological network. } \\
\text { Overarching strategy: } \\
\text { EU Biodiversity Strategy } 2020\end{array}$ & 1992 & 1992 & $\begin{array}{l}28 \text { EU Member } \\
\text { states }\end{array}$ \\
\hline EU Flood Risk Directive & $\begin{array}{l}\text { Aims to reduce and manage the } \\
\text { risks that floods pose to human } \\
\text { health, the environment, cultural } \\
\text { heritage and economic activity. } \\
\text { Requires Member States to } \\
\text { assess if all water courses and } \\
\text { coastlines are at risk from } \\
\text { flooding, to map the flood extent } \\
\text { and assets and humans at risk in } \\
\text { these areas and to take adequate } \\
\text { and coordinated measures to } \\
\text { reduce this flood risk }\end{array}$ & 2007 & 2007 & $\begin{array}{l}28 \text { Member } \\
\text { States }\end{array}$ \\
\hline Paris Agreement & $\begin{array}{l}\text { To enhance the implementation } \\
\text { of the United Nations Framework } \\
\text { Convention on Climate Change } \\
\text { (UNFCCC) through ambitious } \\
\text { climate change mitigation and - } \\
\text { adaptation efforts with the aim to } \\
\text { keep a global temperature rise } \\
\text { below } 2 \text { degrees Celsius }\end{array}$ & 2015 & 2016 & $170 /$ all \\
\hline
\end{tabular}

\subsection{Formal institutional framework for Nordic governance - comparing WFD implementation in the Nordic region}

The EU Water Framework Directive was adopted in 2000, replacing a fragmented set of water related EU policy frameworks (European Parliament, Council 2000). The WFD was developed in an open consultation process involving interested parties, such as local and regional authorities, water users and non-governmental organizations (NGOs). This common water policy framework has two main aims: to protect all inland, freshwater, groundwater and coastal waters in EU and achieve good ecological water status, and to get citizens and stakeholder organizations actively involved in the water 
management process (European Commission, 2003). The WFD implementation process is formed as an integrated, iterative 6-year water management cycle. Information and consultation is mandatory in specific phases of the WFD water management cycle, while active participation is encouraged. The focus on mandated stakeholder participation in the WFD provides a novel mode of EU policy, combining participatory and multi-level governance (Newig and Koontz, 2013). The implementation of the WFD has been supported with guidance documents, policy papers and an arena for exchange of experiences by the Common Implementation Strategy $\left(\mathrm{ClS}^{21}\right)$ established in 2001, led by Water Directors of the Member States and the Commission and with participation of relevant stakeholders.

The WFD follows an ecosystem approach in the sense that waters should be managed according to hydrological boundaries in larger River Basin Districts (RBDs), redrawing the administrative map of water institutions in Europe (CBD, 2004a). This reorganization implies new demands on institutional arrangements at local, national and international levels (Hammer et al, 2011). Transnational cooperation is important for implementing the WFD. In the Nordic region, all countries except for Iceland share one or more RBD with another country, and Finland shares one with Russia, who is not an EU member. Norway and Iceland are connected to the European Union through the Agreement on the European Economic Area (the EEA agreement).

However, the WFD requires only a subset of ecosystem components to be assessed (Borja et al. 2010). For instance, it cannot provide ecosystem-based management in coastal areas, as it does not include assessment of fish populations as a quality element.

The implementation of the Directive is the responsibility of the individual Member States, including setting up the competent river basin authority for each RBD and the necessary national legal and regulatory adjustments. Two general governance models can be distinguished: national and regional approaches to governance (Hedin et al., 2007). In the Nordic countries, Denmark and Iceland have the main authority located at the national level, while Finland, Norway and Sweden have a regional governance approach.

Denmark has 4 River Basin Districts, ${ }^{22}$ divided into 23 main catchment areas. The Danish Nature Agency under the Ministry of Environment ${ }^{23}$ is the competent authority. A River Basin Management Plan (RBMP) is produced and reported for each of the 23 sub-districts. The RBMP plans are legally binding for national, regional and local authorities and there is a general obligation for individual decisions to take the RBMPs into account. International collaboration takes place in the cross-border international district between Denmark and Germany, as well as in the Sound region between Denmark and Sweden (see further, the Sound case study). The cooperation involves the bordering municipalities. The Danish part of the Sound is managed under both the WFD and the Marine Strategy Directive, while the Swedish part is managed only under the WFD.

\footnotetext{
${ }^{21} \mathrm{http}$ //www.ec.europa.eu/environment/water/water-framework/objectives/implementation_en.htm

${ }^{22}$ http://www.mst.dk/natur-vand/vandmiljoe/vandomraadeplaner/om-vandplanlaegning/organisering/

23 http://www.en.mfvm.dk/
} 
Greenland is not an EU member ${ }^{24}$ and does not have a formal system for WFD implementation. The Department of Environment and Contingency Management under the Greenlandic Ministry of Nature and Environment govern water issues on Greenland and three nautical miles from land (and the area between 3-200 nautical miles from land is under Danish jurisdiction). Pollution of the marine environment resulting from Greenlandic wastewater does not at present rank among the more important environmental issues. Wastewater from houses and factories is usually discharged into the sea, mostly after filtration. However, the prospects of future oil and mineral exploitation projects, as well as international attention on water pollution, have recently drawn increased attention to water management in Greenland.

Sweden has 5 River Basin Districts, ${ }^{25}$ of which three are shared with Norway and/or Finland. One County Administrative Board (CAB) in each district is assigned to govern the water district as the Water District Authority (WDA, ${ }^{26}$ Vattenmyndighet). Five Water Delegations (Vattendelegation) comprised of eleven experts appointed by the Swedish government, make the formal decisions on Environmental Quality Standards (EQS), Program of Measures (PoM) and Management Plans for each WDA. At the national level, the Swedish Agency for Marine and Water Management $\left(\mathrm{SwAM}^{27}\right)$ has the overarching responsibility for implementing the WFD and the Marine Strategy Framework Directive. SwAM coordinates the WDAs in implementing the Water Quality Management Ordinance (VFF 2004:660; SFS 2011:619). SwAM also cooperates with other state level agencies, i.e. the Swedish Environmental Protection Agency (SEPA) and the Swedish Board of Agriculture, ${ }^{28}$ and with CABs and municipalities (SFS 2011:619; SWAM 2014). The Water Quality Management Ordinance (Vattenförvaltningsförordningen, VFF 2004:660) prescribes that the WDA is responsible for governance of water quality in their district. This task is completed by determining EQS, constructing a Management Plan and a Program of Measures, constructing a register over protected areas and through constructing and implementing Environmental Surveillance Programmes. All of Sweden's CABs must assist the WDA in the preparations of programs and in coordinating regional water management, as well as in instigating and supporting local Water Boards.

Finland with $8 \mathrm{RBDs}^{29}$ of which two are shared with Sweden and Norway, has integrated the WFD into their existing environmental administration There are 13 governmental regional administration centres (The Centre for Economic Development, Transport and the Environment, ELY-centre ${ }^{30}$ ) that manage the RMBP and Programme of Measures in their areas of operation. Five of the ELY-centres are named as

\footnotetext{
24 http://www.nalakkersuisut.gl/

25 http://www.vattenmyndigheterna.se/SiteCollectionDocuments/gemensamt/publikationer/broschyrer-foldrar/faktabladengelska.pdf

${ }^{26}$ http://www.vattenmyndigheterna.se/

27 http://www.havochvatten.se/en/swam/eu--international/international-cooperation/watercog/swedens-water-

management.html

${ }^{28}$ http://www.jordbruksverket.se/

29 http://www.ymparisto.fi/en-

US/Waters/Protection_of_waters/Planning_and_cooperation_in_river_basin_districts/River_basin_districts

$3^{\circ}$ http://www.ely-keskus.fi/en/web/ely-en/
} 
coordinators of each RBD. Each RBD has a steering group with directors of each ELYcentre in the district. This steering group makes the decisions regarding RBMP. The Ministry of Environment is responsible for cooperation related to the Marine Strategy Development and implementation with the other states in the catchment area of the Baltic Sea. At the national level, national governmental research institutes (such as the Finnish Environment Institute SYKE ${ }^{31}$ and Natural Resources Institute LUKE, ${ }^{32}$ among others) have a supporting role (e.g. development of monitoring and EQS assessment system, data management system, EU reporting, national coordination, tools and models) in the planning and implementation process.

Åland constitutes one basin (RBD 8). The Åland Government is responsible for developing a management plan and an action program for the Åland waters and Åland adjacent coastal waters to RBD 3 in southwestern Finland. Water Framework Directive reporting to the EU is carried out nationally by Finland. The Government of Åland ${ }^{33}$ and its Environment Agency (Miljöbyrån) at the Department of Social Affairs, Health and Environment, prepares the processes involved in the WFD (Water Framework Directive) management cycle, including cooperation with the public and other interested parties. The Water Framework Directive is implemented in the Åland legislation, mainly through the Water Act (1996: 61) and Water Regulation (2010: 93).

Norway, together with Iceland, is connected to the European Union as an EFTA country, through the Agreement on the European Economic Area (EEA). The WFD was formally taken into the EEA-agreement in 2009, granting the EFTA countries extended deadlines for implementation. EFTA-counties reporting obligations are to the EFTA Surveillance Authority (ESA). Norway has taken full part in the Common Implementation Strategy (CIS) for the WFD. Norway performed a voluntary "pilot phase" implementation of the WFD in selected sub-districts 2007-2009. The WFD was transposed into the Norwegian Regulation on a Framework for Water Management, Vannforskriften (The Water Regulation), entering into force in 2007. RBMPs for the entire country were prepared from 2010 until 2015, synchronized with the time schedule of the second cycle of implementation in the EU (vannportalen.no; Hanssen et al. 2016).

The close to 30,000 water bodies in Norway have been grouped into 105 subdistricts and 11 River Basin Districts (RBDs). ${ }^{34}$ Of these, several share watercourses with Sweden, Finland and Russia (vannportalen.no, 2017). Selected County Councils are appointed as Competent Authorities for their respective River Basin Districts. They chair a District Water Board, ensuring the participation and sector integration of all municipal and district authorities.

The WRA is responsible for determining EQS, constructing a Management Plan, Program of Measures, a registry of protected areas and implementing Environmental Surveillance Programmes. All of Norway's local water areas must assist the WRA in the

\footnotetext{
${ }^{31}$ http://www.syke.fi/en-US

${ }^{2}$ https://www.luke.fi/en/

33 http://www.regeringen.ax/

34 http://www.vannportalen.no/globalassets/nasjonalt/engelsk/river-basin-management-planning-at-district-level/the-

water-regulation-divides-norway-into.pdf
} 
preparations of programs, coordinating the regional water management and instigating and supporting local Water Boards. The national authority for the implementation of the WFD is the Norwegian Ministry of Climate and Environment that also chairs a committee of eight ministers to ensure sufficient sector integration. The Norwegian Environment Agency 35 is responsible for administrative coordination and the day-to-day administration of the RBDs, including leading a Committee of Directorates consisting of central government agencies, as well as regional and local level representatives, with the task to prepare national guidance for the RBDs. A National Reference Group is connected to the Committee of Directorates also allowing for the participation of national industry associations, NGOs and civil society representatives (vannportalen.no, 2017).

Iceland has one single river basin district, ${ }^{6}$ divided into four sub-districts. Iceland is connected to the European Union through the Agreement on the European Economic Area (the EEA agreement). The WFD was formally taken into the EEA agreement in 2009 and fully transposed into Icelandic legislation in 2011 (Halleraker et al., 2013). Iceland reports its obligations to the European Surveillance Authority (ESA). The Environment Agency implements the WFD and works with five state institutes/agencies (Icelandic Met Office, Institute of Freshwater Fisheries, National Energy Authority, Icelandic Institute of Natural History and Marine Research Institute), local authorities, water district committees and consultation groups to analyse and classify the water bodies of the RBD.

\subsection{Mainstreaming biodiversity and ecosystem services across sectors in the Nordic region: Examples from water governance and the case studies}

Case studies and examples from water governance in the Nordic region aim to provide an overview of how environmental aspects are integrated across policy areas and of the policy conflicts that arise in this process. Furthermore, water governance and our case studies provide important insights into what policy instruments are in place and how participatory governance is organized in the Nordic region.

\subsubsection{Policy integration across sectors, ecosystem services and scales}

The Sound between Denmark and Sweden provides a relevant example of how successful work for cross-border cooperation and environmental policy integration can be organized. The Sound is the most densely populated area in Scandinavia and one of the most trafficked places in the world's oceans. Since the Sound is a hotspot of almost all kinds of human activities, associated environmental pressures have the potential to affect

35 http://www.miljodirektoratet.no/english/

${ }^{36} \mathrm{http}: / /$ www.government.is/ 
biodiversity and ecosystem function and services. However, our case study shows that the area is a well-functioning ecosystem with a relatively high biodiversity, which may be explained by appropriate standards for environmental protection and a general precautionary approach to the environment that have helped to preserve ecosystems. EU and national spatial planning regulations protect both terrestrial and marine areas and have helped to halt the impacts of urban and agricultural development. In the Sound area, there is a long tradition of municipal and regional cooperation across borders in order to act for a healthy marine environment. Since 1995, this cooperative work has been conducted within "The Sound Water Cooperation". The almost $18 \mathrm{~km}$ long bridge across the Sound exemplifies how highly marine environments and ecosystems are placed on political agenas, particularly in terms of investments in water quality that have made bathing possible in the harbours of Copenhagen and Malmö.

The WFD is implemented in all Nordic countries and therefore provides another relevant point of departure for comparing formal processes for environmental policy integration in the Nordic region. Generally, water governance work is ecosystem based, organized in 6-year water cycles and the process is carried out in cooperation with stakeholders. However, the formal process is organized differently in different countries (see section 6.4). Denmark, Iceland, Finland and Åland have implemented the WFD in line with their existing environmental administration, resulting in consistency in power structures and responsibilities regarding the WFD process in these countries. In Denmark, the RBMP is not binding to individual persons i.e. operators and water users. Therefore, the obligation of compatibility of the RBMP with other decisions and plans applies to the RBMP in its entirety. In Finland, one of the main challenges in the water area is the vague nature of the RBMP and Management Strategies. Plans are not considered legally binding for the authorities, but something they should take into account in their decision-making (e.g. plans, permits, municipal environmental regulations) (Kauppila 2016). Furthermore, implementing additional measures is mainly voluntary for both public and private actors. Sweden and Norway have created new institutional arrangements for water management, which has given rise to confusions regarding the power structures within the systems. In Finland, Sweden and Norway, Management Plans and Programmes of Measures are established for each river basin based on the EOS and after discussion within stakeholder groups. However, although the Swedish WDAs/Norwegian WRAs set the goals for water governance, the responsibility to implement the Management Plans and Programmes of Measures rests heavily on municipalities and national authorities. The Programmes of Measures thus forms a meta-regional level authority that provides guidelines both downwards to municipalities and upwards to state agencies, which report back on their undertaken measures to the meta-regional river basin district authorities. As a result, Swedish SwAM/Norwegian NEA first receive directives from the WDAs/WRAs, then report their undertaken measures back to the WDAs/WRAs and finally receive compiled reports from the WDAs/WRAs following their reporting to the EU. Sweden's new and untraditional power directions within the country's system for water governance have been pointed out as one reason for difficulties in reaching the goal of good water quality (Söderberg, 2016). 


\subsubsection{Policy coherence}

One obstacle for successful integration of biodiversity goals and other environmental goals is policy conflicts. In practice, biodiversity and water quality goals can be in conflict with other targets influencing the water environment, such as flood risk management, climate change, tourism, infrastructure development and agriculture. Examples of detected policy conflicts in case studies and management of water in the Nordic are presented below.

The Sound: Although the Sound provides a good example of cross-border cooperation and environmental policy integration in practice, there are also some examples of policy incoherence that need to be addressed. It is relevant to note that the Swedish Sound part is managed under the WFD (with stricter demands for management plans), while the Danish part of the Sound is managed by a combination of the WFD and the Marine Strategy Framework Directive (MSFD), a process which is less finalised and currently negotiated in HELCOM. Furthermore, areas protected by Natura 2000 must fit under a specific designation basis - the habitat type has to be listed in the Habitats Directive Annex I. The Danish national Nature Protection Act protects coastal areas, while the Marine Environment Act protects marine areas. Given that different Directives and different regulations are in place, protection of the Sound as a whole would require cooperation from both sides of the Sound - Denmark and Sweden - causing the need, although much integration is done already, for more work streamlining or developing special protection legislations in the area (see Petersen et al., 2018). Furthermore, Swedish sector authorities and County Administrative Boards have signalled that water issues are one of the areas of their work that often conflicts with goals and priorities in other policy areas (SEPA, 2011). Similarly, Söderberg (2016) concludes that Swedish water bureaucrats experience the goals in the Programme of Measures as vague and difficult to understand and point out a number of other regulations that limit the practical space for implementing measures according to the Programmes of Measures. In addition, different authorities handle the different regulations that affect water quality work, and they all have different perceptions of how efforts should be balanced between water quality and other issues such as agricultural competitiveness, forestry, societal planning, renewable energy production, employment policy and economic development (Söderberg, 2016).

Kalix: One area often forwarded as a successful Swedish participatory governance/co-management example is the professional bleak roe fishing in the waters around Kalix (see e.g Rova, 2004). At the same time, the ILK case study of the Kalix area (see Kvarnström \& Boström, 2018) in Sweden shows that the possibility to continue traditional small-scale artisanal fishing for household needs has been negatively influenced by extensive changes in regulations. The Kalix case study shows how multilevel governance structures and many different policies clash with resulting negative impacts on local people's way and quality of life. At present, there is an extensive network of authorities that create, implement and oversee compliance of regulations relating to fishing in the coastal waters of the Bothnian Bay. The new fishing regulations regarding fishing and the selling of fish have meant that local community members in the Kalix area no longer can catch their own fish or sell any surplus as previous 
generations did. At the same time, the number of seals in the Baltic Sea and the Gulf of Bothnia have increased significantly, as has seal-related damage to fish and fish equipment, while protective hunting of seals is regulated on several levels. The most complicated example of the fishing regulations is the professional salmon fishing and salmon fishing with fixed fishing gear on private waters. These activities are surrounded with a very complicated regulatory framework where virtually all agencies have a part, ranging from EU quotas on salmon to national catch allocations, to regional and local rules that regulate dates and quotas and the distribution of catches between river and coastal waters. There is no co-management at present, but a local organisation, Kustringen, has carried out eco-mapping and mapping of fish and fishing for several years. Proposals have been made for the introduction of local fishing regulations involving the local population in monitoring and governance (see Kvarnström \& Boström, 2018). However, so far this ambition has not led to anything in practice in terms of co-governance.

Åland: A number of policy conflicts are reported on in relation to water and biodiversity management in Åland. One conflict between Åland and Finland concerns the total allowable catch (TAC): a catch limit (in tonnes or number) that is determined for the fish stocks that have the highest commercial value. Countries must use clear and objective criteria when allocating national quotas for its fishermen. They are required to ensure that quotas are not exceeded. Another policy conflict relates to fish farms in the Baltic Sea, which have negative environmental impacts on aquatic ecosystems. However, they also constitute an important source of income in the Åland archipelago (ÅSUB 2015). A sharp cut of fish farming operations would have major social and economic consequences, but a reduced nutrient load is good for the aquatic environment and its ecosystem services: a reduction of excessive nutrients is needed to prevent eutrophication and improve the Ålandic water status (including wild fish stocks). The possible development of the aquaculture industry must comply with the requirements for the improvement of water quality in accordance with the WFD), HELCOM's Baltic Sea Actions Plan and recommendations and the Åland marine strategy (Directive 2008/56/EG) (see Vävare \& Häggblom, 2018): Two recent EU Commission judgments, the Weser Judgement and Schwarze Sulm, clarify the application of Article 4 of the WFD. Member States are required to not grant permission for a project if the project can cause deterioration of a surface water body or if the project compromises the achievement of good status of a body of surface water. The strict conditions make it difficult to allow the establishment of new fish farms in coastal waters with moderate or poor water status, such as in the Baltic Sea. This was made very clear in a Swedish judgment in March 2017 concerning fish farms in waters around the High Coast in Sweden.

Helgeland: Helgeland in Norway, like many areas in Nordic water management, is subject to many conflicting interests of both economic and ecological development. In an attempt to find a way forward and balance the different goals and needs in the area, a regional coastal plan has been developed between 13 local authorities (see Hancke et al., 2018). 
The Quark: In the case study of the Quark between Sweden and Finland, insights into how cross-border cooperation can be organized according to an ecosystem-based approach in order to achieve a coherent management program are presented. The intergovernmental governance of the Quark strait has been developed through official cooperation programs between regional authorities. The Kvarken Council is a political cross-border dialogue platform formed by the cities of Vaasa, Kokkola, Seinäjoki and Jakobstad, the three Regional Councils of Ostrobothnia in Finland, as well as the Regional Council of Västerbotten and the city of Örnsköldsvik in Sweden. It was founded in 1972 and the board has six members from Finland and six from Sweden. The Council is one of eleven official cross-border operators funded by the Nordic Council of Ministers. The Council is registered in Finland and Finnish law is applied. The chairmanship is circulated between the cities of Vaasa and Umeå (two years each) (see Ilvessalo-Lax et al., 2018).

Disko Bay: Obtaining coherent biological knowledge in the Arctic is generally difficult, expensive and dependent on long-term monitoring activities, since many species are distributed over vast areas. In addition, extreme weather conditions, remote locations and expensive logistics and transportation may limit the biological knowledge about particular populations. Thus, lack of data leads to biological advice that often creates controversy between the scientific community and the fishers and hunters. Fishers and hunters have accumulated traditional ecological knowledge for decades and therefore often find it difficult to understand and accept the notion of lack of data (Ministry of Environment and Nature 2014). This case study also demonstrates that local people are expected to contribute to monitoring initiatives without any economic compensation (see Poulsen, 2018).

Faroe Islands: The Faroe Islands constitute a self-governed (autonomic) part of the Danish Kingdom with their own legislative parliament (Føroya løgting) and government, which is chaired by the prime minister (løgmaður) and two other ministers. The Faroes are organized in 30 municipalities, the largest being Tórshavnar with 20,885 inhabitants in 2017. Although Denmark is a member state of the European Union, the Faroe Islands have chosen to remain outside the union. Accordingly, the Faroe Islands negotiate their own trade and fisheries agreements with the EU and other countries. A treaty between the Faroe Islands and Denmark, which is enacted in legislation, provides Faroese autonomy in foreign relations. The Faroe Islands participate actively in a range of international fisheries management arrangements and organisations in the North Atlantic. Marine environmental protection is regulated according to the Marine Environmental Act, with regulations implemented in line with requirements under international conventions such as the MARPOL convention for the Prevention of Pollution from Ships and the OSPAR Convention for the Protection of the Marine Environment in the North Atlantic. The responsible authorities are the Environmental Agency, the Faroese Maritime Authority and the Faroese Fisheries Inspection. To take care of the rich bird life in the Faroe Islands, the government has appointed three areas as Ramsar sites: Mykines, Nólsoy and Skúvoy. Several national acts and decrees exist to protect the nature and limit the use of resources. A number of emerging policy conflicts are visible here, including different opinions regarding whale 
hunting, and between ecosystems and tourism expansion. Furthermore, the increasing levels of plastic pollution, industrial chemicals, heavy metals and PCBs found in fish, pose an international threat to the traditional Faroese food culture (see Sørensen, Roto, \& Tunón, 2018).

\subsubsection{Participatory measures in the implementation of policy}

Participatory measures are central to the governance of biodiversity and ecosystem services - and for water management - in all Nordic countries, but these processes are organised in different ways. In this section, policy instruments such as cross-border cooperation and participatory measures from water governance and case studies, are presented and discussed.

In the Sound case study, it is pointed out that there is a well-developed cross-border cooperation between municipalities/regions and environmental authorities. High policy density in the Sound has led to incoherence and thus streamlining and developing strategies is needed. However, although there are on-going initiatives for stakeholder participation in the regional association "Öresundsfiskarna" with hopes to bridge opinions between fishers, the case study shows that there is a need for participation and communication between authorities and commercial/ recreational fishers in the area. This is particularly relevant as marine protected areas often conflict with fishing interests. Commercial and subsistence fishers in Scania currently feel marginalised and call for more knowledge and flexibility amongst local authorities, along with a looser regulatory framework as the current framework limits potential to develop local markets. These issues could be relevant to address when planning for marine protected areas in the Northern parts of the Sound (see case study the Sound: Tunón, ed., 2018).

At the same time, the Swedish part of the Sound is managed under the WFD, while the Danish part is managed under a combination of the WFD and the EU Marine Strategy Framework Directive (MSFD, which provides a number of different examples of how stakeholder participation can be organized. Different authorities handle different regulations that affect water quality work, each with different perceptions of how efforts should be balanced between e.g. water quality and water use. Marine managers identify the Sound as part of the Greater North Sea, due to its marine nature and the presence of the shallow sill at its southern end. River basin managers identify the Sound as part of the Baltic, due to the watershed at its northern end. Even smaller catchments used to group measures on land, do not match the marine underwater topography. These mismatches can cause difficulties when evaluating work at a regional level.

In Sweden, participatory measures within water governance are visible mainly within two administrative schemes: the Water Delegations (a maximum of eleven expert delegates making formal decisions in each Water District) and the Water Boards (125 local Water Boards, open for all actors affected by the water who participate water governance decision-making). Water Boards do not make any decisions, but are informal organisations for local cooperation. They enable dialogue with water 
stakeholders within a water district and accumulate local knowledge (Swedish Water Authorities, 2014a). Through providing a forum for discussing and adjusting proposals before decisions are made, the Water Boards represent an attempt to make sure that decisions on water management are easier to implement for authorities and municipalities (Swedish Water Authorities, 2014b). However, their status is unclear, as is the relationship between municipalities and water authorities. Local cooperation in local watersheds is important, in particular regarding issues such as nutrient leakage affecting eutrophication, where active participation from landowners is required for successful mitigation. Successful collaboration regarding concrete measures to improve the environment, such as wetland construction programs, are heavily dependent on the institutional setup regarding stakeholder participation (Franzén et al, 2015). The Swedish organization for stakeholder participation under the WFD can be compared to stakeholder participation for water and marine management in Finland, where each ELY-centre nominates a cooperation group consisting of representatives of regional stakeholders from relevant public and private sectors. The cooperation group is then consulted during the preparation and implementation of the RBM plans/PoM and marine strategy. Regional Councils provide environmental support for environmental initiatives and are responsible for land use planning. Regional Councils are also responsible for Marine spatial planning (according to the EU MSP directive) in cooperation with several other councils and regional actors. In Åland, Water Framework work has led to cooperation in several different stages and at different levels, both locally in Åland, nationally with Finland and internationally in cooperation with the other Nordic countries. Consultation and information meetings are held in conjunction with the development of management plans. Initial information meetings often result in more specific meetings on agriculture, forestry, fish farming and meetings for agencies of the provincial government and subordinate agencies, as well as invitations of various industries and operators to consultations. Municipalities, NGOs, politicians and the public are invited to information meetings through the yearly aquatic seminars organised by the Environment Agency. The meetings result in a list of different measures proposed for water bodies, where the need for different tools and resources are pointed out. The Environment Agency compiles information gained through the consultation process and develops proposals for action. Consultative rounds are run with as many stakeholders as possible (e.g. politicians, other authorities, operators and NGOs). To ensure transparency, the public is informed of their opportunity to respond to material available on government websites through advertisements in local media. Once the documents are finalised, the Environment Agency initiates consultations with the elected politicians in the government. The Åland Government then makes the final decision on determining the river basin management plan and the water action program for the Åland waters. When the decision is made, it is up to the Environment Agency to co-report to the EU (via Finland) and initiate the implementation of the Water Action Plan and other strategic work linked to the management cycle.

The Disko Bay case study (Poulsen, 2018) points out that Greenlandic governance institutions have been criticized for their colonial heritage of centralization and lack of democratic participation. In the same manner, Greenlandic fisheries management is 
notorious in academic literature for its centralized and locally illegitimate character (Jacobsen \& Raakjær, 2012). Greenlandic governance institutions are subject to the power structures taken over from Denmark at the inception of Home Rule on May 1, 1979 (Jacobsen \& Raakjær, 2012). Participatory decision-making does not necessitate bottom-up democracy and equity, nor does it always play a role in increased efficiency (Jacobsen \& Raakjær, 2012). Since 1999, the Hunting and Fishing Law in Greenland has required local knowledge to be considered in the government's decision-making. It has however been difficult to do so in practice, as it is almost impossible for decisionmakers to get information on the local knowledge. Advice from scientists is often based on systematic scientific research by biologists from the Greenland Institute of Natural Resources (GINR) and the Danish Centre for Environment and Energy (DCE). The quality of this research is reviewed and approved by other scientists. Advice based on local knowledge is rarely based on systematic observations and approved by other local experts. It is therefore not surprising that decisions regarding the use of living resources are based more on advice from biologists than advice from fishers and hunters. The parties Siumut, Inuit Ataqatigiit and Partii Naleraq have entered a coalition agreement where it is said that management decisions should be based on advice from both biologists and users (fishers and hunters). In the GINR strategic plan for 2013-2017, the Institute recognizes that fishers and hunters hold extensive local knowledge of the Greenlandic nature, which should be included in the scientific work of the Institute. Our Disko Bay case study in Greenland provides one example of involving local citizens in environmental monitoring (i.e. a community-based monitoring system). Fisheries control is partly carried out by reporting from fishermen. The method of reporting depends on boat size. Boats under 30 feet / 9.4 meters must report catch to the place of purchase. Boats over 30 feet / 9.4 meters must keep an updated logbook with recordings of all catches. Hunters must report all catch annually via the Greenland hunting and catch registration system "Piniarneq". Standardized monitoring of the catch is based on Piniarneq. The information from fishers and hunters however, needs quality assurance in line with scientific data, as the Institute must not compromise on scientific methods.

\subsubsection{Innovative governance in the Nordic: co-management examples}

In the Nordic region, there are a few examples where participatory management has been taken one step further - towards co-management. In this section, innovative governance solutions for biodiversity and ecosystem management in Laponia and Näätämö are presented. In the last part of this section, an example of ILK-involvement in governance from Disko Bay in Greenland is presented.

Collaborative management and joint governance is usually, if it has legal or meaningful mandates, thought to be constructed from a dual approach: 1) Joint knowledge flows from ILK and science to inform decision-makers of the situation, baselines and changes in a given context; 2 ) joint decisions (usually consensus or 5050) on the uses and governance of natural resources and territories. It is also expected to result in better compliance when it comes to specific decisions. Actual arrangements 
may vary. The various official recognitions of ILK and local-traditional knowledge depend on the scale and level of governance. Internationally, there is a wealth of academic literature on management initiatives that focus on the inclusions of ILK. For the Nordic countries, the situation differs greatly. Out of the arrangements in place, only Laponia and Näätämö (see further details below) are recognized internationally as "true" collaborative management initiatives, as they contain the two-tiered model of knowledge flow leading to joint management. Co-management systems, provided that they contain the principles and context of co-governance, should be seen as an innovative tool for the future and good governance of biodiversity in the Nordic space.

Laponia: Sweden has implemented the first-ever official collaborative management system in the Nordic countries, in the large national parks known jointly as Laponia ${ }^{37}$ in Norrbotten, Sweden. The region is also protected as a UNESCO World Heritage site due to the presence of strong Saami culture, ways of life and economies both outside and inside the parks. The World Heritage site was founded in 1996, but the management structure was not easy to develop in a way that was acceptable to the stakeholders. Hence an agreement was reached in 2006 to develop a structure of comanagement. The co-management function Laponiatjuottjudus was launched in 2013. The road to an organization that was acceptable to the different stakeholders, was long and filled with disagreement. It took a lot of effort and new legislation in order to create a new management organization. Governance of the parks and the environment rests on consensus between local Saami villages, municipalities, county administration and the state (see e.g. Zachrisson, 2009). Therefore, Laponia is often hailed as the "best existing model" for the governance of aquatic and terrestrial ecosystems in the European North.

Näätämö: The first collaborative management project in Finland was initiated in 2011 in the Näätämö river basin, with funding from the United Nations and Nordic Council of Ministers. The key organizations participating in the co-management of Atlantic Salmon resources include Metsähallitus, ${ }^{38}$ Institute of Natural Resources LUKE and the ELY-centres. The Saa'mi Nue'tt cultural organisation, the Skolt Saami Village Council and the international Snowchange Cooperative form the key components of this co-management arrangement. Näätämö co-management has no legal status. Instead, it is an on-going project that implements the methods and structure of a full arrangement of joint governance - the first of its kind in Finland. In short, the knowledge flow combines Indigenous Saami and local-traditional knowledge of observations, monitoring, cultural indicators and locations of altered ecosystems with the latest scientific and limnological interpretation to offer a view of the basin. The Näätämö co-management project has taken some pilot-style steps to restore lost habitats due to past land uses, such as the Vainosjoki sub-catchment area. ILK and science is used to improve living conditions for salmonid species, Skolt Saami and other users of the river. The Näätämö project works closely with the Inuvialuit Joint

\footnotetext{
37 https://laponia.nu/en/

$3^{8}$ http://www.metsa.fi/web/en
} 
Secretariat in Northwest Territories in Canada, to investigate, analyse and exchange experiences of collaborative management (Mustonen, 2018a).

Näätämö basin is under the jurisdiction of the Finnish-Norwegian border river treaty. The general tendency in the Finnish case study areas (see the Näätämö and Puruvesi case studies: Mustonen, 2018a \& b) is a system of top-down governance of natural resources, ecosystems and socio-ecological systems. This can potentially result in a number of slow-simmering conflicts, which do not necessarily expand into open conflicts, but contain abrasive experiences for local and indigenous stakeholders. While in Näätämö basin positive steps have been taken over the past five years through the first co-governance of the Atlantic Salmon, ultimately the fisheries and management of the river still rests with the Ministry of Agriculture and Forestry and FinnishNorwegian border river commission. This means that the Skolt Saami, the primary Saami group involved in this river, feels their ILK and ways of being with the river are not heard or taken into consideration when power is exercised in the basin. Puruvesi Lake is divided between two administrational regions, South Savo and North Karelia. It is the home of the most traditional seining culture in Finland, with records from the beginning of the 1300s. In the 1990s, the negotiations between Metsähallitus and the commercial fishers of the lake, resulted in seines and fish traps only being used on the lake to preserve the unique vendace stocks. This began to shift so that trawling was permitted on the lake by the end of 2010. Potential other future conflicts include the harvest of gravel from the lake bottom on Puruvesi and the erosion of the Savo Karelian border for commercial harvests to allow "outsiders" to operate on this extremely productive fishery.

Overall in Finland, many coastal and aquatic systems portray elements of joint governance, and more recently Akwé: Kon guidelines (CBD, 2004b) in times of conflict (Full name: Akwé: Kon Voluntary guidelines for the conduct of cultural, environmental and social impact assessments regarding developments proposed to take place on, or which are likely to impact on, sacred sites and on lands and waters traditionally occupied or used by indigenous and local communities). These include, for example, the local fisheries bodies, which have the power to decide on stocking and restoration measures within their jurisdiction. Policy analysis shows however, that the level of governance and power to rule over natural resources remains weak. These systems are more to be seen as state governance than shared responsibility. Therefore, concepts of joint governance and co-management that address past equity issues with the Saami, or address other grievances in natural resources management in Finland, should be contextualized as early emerging systems at this stage.

Disko Bay: In Greenland, The National Institute gathers information from local knowledge through meetings with resource persons during the planning of studies, the creation of local networks with active involvement in research projects, collaborative projects, scientific interviews and information from catch and fishing reporting. However, when the scientific advisers lack data based on biological research, they advise according to the precautionary principle, and hunters and fishers claim that populations of certain species are larger than the figures the restrictions and quotas are based on. Systematic data gathering and a process for reviewing and approval are 
therefore needed if hunters and fishes are to be heard. This is why a number of authorities and organizations, including the Ministry of Fisheries and Hunting (APN), Qaasuitsup Municipality and KNAPK, have since 2008 been testing the use of locallybased monitoring of living resources in communities in Disko Bay and other places in Qaasuitsup Municipality in North West Greenland under a program called PISUNA. ${ }^{39}$ In the PISUNA program, village councils appoint 5-12 members of local Natural Resource Councils, comprised of experienced fishers, hunters and other environmentally interested people. They observe the living resources and the marine and coastal environment whenever they travel, fish and hunt. Every three months they summarize, discuss and interpret their observations. They propose management recommendations to the municipal government and they submit a standardized report with their findings to the municipal and central government. PISUNA was at first met with considerable skepticism from both scientists and local hunters and fishers. Most of this skepticism has since been overcome as the program has addressed challenges, tested solutions and adapted as required. The program therefore now provides a great example of how local people can participate in environmental monitoring in Greenland and elsewhere (Poulsen, 2018).

\subsection{Opportunities and challenges for policy and decision-making}

The overview and the examples provided in this chapter show that biodiversity goals are difficult to implement in practice, even in the "green" Nordic region with a longstanding culture of consensus building and cooperation. Policy density is high, with a lot of different policies to handle: this affects policy integration and policy coherence and a number of emerging and on-going policy conflicts are evident. With many different objectives to achieve, policy makers and bureaucrats need to weigh the costs and benefits - and prioritize - not only between economic/social goals and ecological goals - but also between different environmental goals. In addition, integration of ILK through stakeholder participation, as well as cross-regional and cross-border cooperation and coordination, is necessary in many cases to make sure that policies are coherent, built upon correct information and able to balance different policy goals and interests. Many stakeholders want to safeguard their interests and put pressure on politicians and decision makers to make favourable decisions. In such a context, the ILK-groups are generally seen as relatively weak groups. Despite similarities in political culture, different solutions for participation and ILK-integration exist in each country. A number of examples of when cooperation across borders works well in order to overcome policy conflicts and national boundaries has also been provided.

A number of different challenges need to be handled in the future. The case study areas in this report, and the examples given in this chapter, are subject to slightly different preconditions and thus slightly different challenges with regard to biodiversity

39 http://www.iucn.org/news/marine-and-polar/201701/pisuna-community-based-monitoring-management 
management. The Sound area is crowded. The Helgeland Coast and the Quark, Kalix, Laponia, Näätämö, 254Puruvesi, Disko Bay and Faroe Islands are large and sparsely populated areas. The Baltic Sea around Åland is affected by the actions in the many different nations surrounding it. Environmental problems in the Faroe Islands are at large caused by pollutions spread from other parts of the Atlantic.

In the Sound, trends of declining fish stock and increasing local pressures have been observed. The consequences of these pressures depend on future handling of existing administrative tools and regulations. Eutrophication load has been lowered locally, but it is difficult to handle the load coming from Kattegat and the Baltic Sea. At the same time, two different national policies, a number of regional and local policies, along with two EU policies (Marine and Water policy) need to be coordinated, in order to reach a coherent policy for the Sound. However, the case study also shows that people are starting to take action in the Sound because they want to protect their environment, even though they are not required to. The case study of the Helgeland Coast shows that kelp forests are important carbon sinks, but these areas are not protected by policy: this is a challenge for future policy to handle. Different challenges for artisanal fishing, stakeholder involvement and flexibility in administering the EU-regulations exist in Kalix and in the Sound.

Thus, one challenge for policy-makers and bureaucrats to handle is how different international policies and EU-directives are implemented in national policy - and to coordinate this across policy sectors, policy levels and national borders, while inviting all relevant stakeholders into this process. It is important to balance ecological, social, cultural and economic aspects in decisions regarding the use of biodiversity and ecosystem services. Since climate change will affect Nordic marine biodiversity profoundly in the future, it is of paramount importance that efficient governance is developed for other pressures, as to mitigate its effects on ecosystem services. Less overfishing, less eutrophication, less pollutants and better land-use and nature protection, are measures that will improve the resilience of Nordic coastal environments (see also Chapter 4 in this report: Svedäng et al., 2018). In designing new governance systems to manage biodiversity and ecosystem services, another challenge is to deal with different transitional problems that may arise with institutional reorganization, such as those we see in both Sweden and Norway. One example of this is the role of national and regional water authorities in relation to municipalities in Sweden, where unclear power structures has led to uncertainties regarding who has the responsibility for what. Knowledge regarding the management of ecosystem services that takes departure from the ecosystem itself, instead of departing from the administrative structure, is lacking and needs to be developed. The challenge is how not to drown in detailed data requirements when imposing new governance models. 


\subsection{Detected uncertainties and options for the future}

Biodiversity goals are difficult to implement in practice, even in the "green" Nordic region with a long-standing culture of consensus building and cooperation. Knowledge gaps regarding ecosystems and their function need to be addressed in order to ensure their continued provision of ecosystem services. The importance of these services need to be highlighted for society and the link between biodiversity, ecosystem services and local cultural identity needs to be identified. Ecosystems need to be managed in a way that makes the most common good today and for the future.

In order to address priorities, risks and trade-offs, monitoring of ecosystems in sparsely populated areas with many water bodies needs to be developed. Here, both ILK and scientific knowledge is needed to get the full picture of biodiversity and ecosystem services challenges and possible solutions. Consequently, to develop good governance, there is a need to include more citizen science and community based monitoring systems in decision-making.

Furthermore, more social science research on already existing ecosystem based management systems, on participatory and collaborative management solutions currently in place, and on policy coherence within international, EU and Nordic environmental management is needed. This will help to improve the design of systems for governance and provide guidelines for how to handle policy conflicts and trade-offs in a way that ensures participation and enhances biodiversity and ecosystem services.

The EU Strategy for biodiversity and ecosystem services, along with other international policy directives, have led to increased awareness and action at all policy levels and across sectors within the EU. However, biodiversity and ecosystem services are not a prioritized issue from political and economic perspectives. Other issues are generally seen as more important. The WFD and our case studies provide illustrative examples of the need for a transformation in awareness and demands for new institutional settings to tackle environmental issues, where ecosystem services provide a powerful tool that is now being introduced in local municipal planning in for example Sweden. The heterogeneity both in institutional and ecological settings, and the different preconditions in the Nordic countries, emphasize the need for adaptive and flexible policy instruments for sustainable governance. At the same time, increased cooperation is needed between local stakeholders, as well as across borders (Halleraker et al., 2013). The current systems for handling these issues in the Nordic region attempt to ensure stakeholder involvement and ecosystem based management. However, the different Nordic management systems all struggle with different problems regarding power structures, trade-offs and policy conflicts.

It is essential to note that as environmental policy integration in all policy areas is a requirement (under the EU treaty) for all EU member states, environmental issues should not be treated as special interests - rather, environmental issues are of relevance for all of society and should be taken into account within all sectors - in energy policy and land use planning, as well as in policies for climate change mitigation and adaptation. Biodiversity and ecosystems services are fundamental for the longterm survival and development of human society and are linked to various policies that 
aim to promote human well-being and improve resilience and sustainability of society. Therefore, the concept of ecosystem services, including consistent evaluation and assessment approaches, should be mainstreamed in all policies (e.g. health, education, transport, land-use, environment, etc.).

At the same time, it is important to highlight the need for clear political guidance on how to handle the detected policy conflicts arising from contradicting policy signals. How should bureaucrats prioritize when balancing different EU directives, national laws, environmental and economic interests etc.? Our case studies and focus on water quality management in the Nordic region indicate that contradictive policies and lack of clear guidelines for how trade-offs are to be made constitute a major obstacle for achieving healthy biodiversity and ecosystem services. It is also essential to follow-up on the need for better data - monitoring programs and priorities that are based on a systems thinking need to be designed. They need to allow for comparative analyses adapted to policy priorities and trade-offs. Furthermore, future governance systems that are able to meet uncertainties and adapt to new knowledge need to be developed if a coherent system for biodiversity management is to be achieved.

\subsection{Knowledge gaps}

- It is essential to follow-up on the need for better data - we need to design monitoring programs and priorities that are based on a systems thinking and allow for comparative analyses adapted to policy priorities and trade-offs;

- There is a need for a better understanding of the role and impact that institutions and governance on different levels have on biodiversity and ecosystem services. For this, we need more social science research on already existing ecosystem based management systems, on participatory and collaborative management solutions currently in place, and on policy coherence within international, EU and Nordic environmental management, in order to be able to improve the design of systems for governance and provide guidelines for how to handle policy conflicts and trade-offs in a way that ensures participation and enhances biodiversity and ecosystem services.

\subsection{Policy recommendations}

- Environmental policy integration in all policy areas is a requirement for all EU member states. It is recommended that environmental issues should not be treated as special interests. Environmental issues are of relevance for all of society and should be taken into account within all sectors;

- The concept of ecosystem services, including consistent evaluation and assessment approaches, should be mainstreamed in all policies. Biodiversity and ecosystems services are fundamental for the long-term survival and development 
of human society and are dependent on various policies that aim to promote human well-being and improve the resilience and sustainability of society;

- There is a need to prioritize between different environmental goals, not only between economic/social goals and ecological goals. Policy density is high - with a lot of different policies to handle: this affects policy integration and policy coherence. Emerging and on-going policy conflicts highlight an increasing need to prioritize;

- It is recommended that the ongoing integration efforts should continue in the Nordic region. Stakeholder participation, as well as cross-regional and crossborder cooperation and coordination, is necessary in many cases in order to make sure that policies are coherent, buildt upon correct information and are able to balance different policy goals and interests;

- To investigate what legislation and regulations that counteract incentives for the conservation and sustainable use of biodiversity in coastal areas in the Nordic region in order to avoid policy conflicts and improve policy coherence;

- Involve science-based assessments and priorities in policymaking in terms of identifying most needed conservation and management policy initiatives;

- Safeguard the right to public access of coastal areas, as access to nature maintains access to a number of non-material NCP, such as identity, physical and psychological experiences, knowledge and inspiration, as well as material benefits such as food and ornaments. This collectively helps maintain society's sense of duty to protect the environment;

- Implement ecosystem-based adaptation to increase the coastal region's resilience to climate change;

- Draw benefits from technological developments that reduce the region's ecological footprint. 


\subsection{References}

Aarhus Convention (1998). Convention on Access to Information, Public Participationin Decision-making and Access to Justice in Environmental Matters (Aarhus, 25 June 1998).

Berthelsen, T. (2014). Coastal Fisheries in Greenland. Nuuk: KNAPK. Available from: http://www.coastalfisheries.net/wp-content/uploads/2013/o6/Coastal-fishing-inGreenland.pdf

Bothnian Bay Programme of Measures (2009). Åtgärdsprogram Bottenvikens vattendistrikt 2009-2015. Länsstyrelsens rapportserie 2010/1. Vattenmyndigheten Bottenviken.

Convention on Biological Diversity (CBD). (2004b). Akwé: Kon Guidelines. Secretariat of the Convention on Biological Diversity, Montreal, Canada.

Convention on Biological Diversity. (CBD). (2004a). The Ecosystem Approach. Secretariat of the Convention on Biological Diversity. Montreal, Canada.

Danielsen et al. (2014). Counting what counts: using local knowledge to improve Arctic resource management. Polar Geography, Vol. 37, No. 1, 69-91, http://dx.doi.org/10.1080/1088937X.2014.890960

Eckerberg, K., Zachrisson, A., Mårald, G. (2012). Samverkan i Bottenvikens vattendistrikt: analys av vattenrådsarbetet. Länsstyrelsens rapportserie 6/2012. Länsstyrelsen i Norrbotten.

European Commission (2002). Common Implementation Strategy for the Water Framework Directive (2000/60/EC) Guidance Document no. 8. Public Participation in Relation to the Water Framework Directive. Working group 2.9-PublicParticipation. Luxembourg.

European Commission (2012). Report from the COmmission to the European Parliament and the Council on the implementation on the Water Framework Directive (2000/60/EC) River Basin Management Plans. Denmark. Com (2012)670 final.

European Commission (2015). The Water Framework Directive and the Floods Directive: Actions towards the 'good status' of EU water and to reduce flood risks. Brussels, 9.3.2015 COM (2015) 120 final.

European Commission (2015). The Water Framework Directive and the Floods Directive: Actions towards the 'good status' of EU water and to reduce flood risks. Brussels, 9.3.2015 COM (2015) 120 final.

European Communities (2003). Planning process, common implementation strategy for the Water Framework Directive 2006/60/EC. Guidance Document No. 11.

European Communities (2003). Planning process, common implementation strategy for the Water Framework Directive 2006/60/EC. Guidance Document No. 11.

European Parliament and the Council of the European Union (2000). Directive 2000/60/EC of the European Parliament and of the Council establishing a framework for the community action in the field of water policy.

European Parliament and the Council of the European Union (2000). Directive 2000/60/EC of the European Parliament and of the Council establishing a framework for the community action in the field of water policy.

FAO. 2016. Country Profile Fact Sheets. In: FAO Fisheries and Aquaculture Department [online]. Rome. Updated 22 February 2017. [Cited 29 April 2017]. http://www.fao.org/fishery/facp/GRL/en

Franzén, F. Hammer, M. \& Balfors, B. (2015). Institutional development for stakeholder participation in local water management-An analysis of two Swedish catchments. Land Use Policy. 43: 217-227.

Grønlands Naturinstitut. (2013). Strategiplan Grønlands Naturinstitut 2013-17. Grønlands Naturinstitut.

Gullestrup, H. (1976). Bygdemsamfund i Grønland. Rapport om nogle udviklingsproblemer. Nyt fra samfundsvidenskaberne (37). J.J trykteknik A/S, Denmark. Danish.

Halleraker et al. (2013). Nordic collaboration on implementation of the Water Framework Directive. Status and further challenges. Report: Nordic Council of Ministers. 
Hammer, M. (2015). The ecosystem management approach - Implications for marine governance. In: Gilek, M. and Kern, K. (Eds.) Governing Europe's Marine Environment. Ashgate Publishers.

Hammer, M., Balfors, B., Mörtberg, U., Petersson, M., Quinn, A. (2011). Governance of water resources in the phase of change - a case study of the implementation of the EU Water Framework in Sweden. AMBIO 40 (2), 210-220, http://dx.doi.org/10.1007/s13280-010-0132-2.

Hancke, K., Gundersen, H., Magnussen, K., Postmyr, E., Andersen, G. S., Jacobsen, K. O., \& Tunón, H. (2018). Helgeland. An Atlantic Archipelago (pp. 171-200). In H. Tunón (Ed.). Nordic IPBES-like Assessment of Biodiversity and Ecosystem Services in Coastal Ecosystems. Case Areas. TemaNord 2018:532 Copenhagen: Nordic Council of Ministers.

Hanssen, G. S., Hovik, S., Indset, M., \& Klausen, J. E. (2016). Sammen om vannet? Erfaringer fra vannforvaltningen etter EUs vanndirektiv. [In Norwegian: Together for water? Experiences from management om water resources after implementation of the EU Water Framework Directive]. NIBR-rapport 2016:22, Oslo: NIBR og HiOA.

Hedin, S., Dubois, A., Ikonen, R., Lindblom, P., Nilsson, S., Tynkkynen, V-P., Viehhauser, M., Leisk, Ü., \& Veidemane, K. (2007). The Water Framework Directive in the Baltic Sea Region Countries-vertical implementation, horizontal integration and transnational cooperation. Nordregio. 2007:2.

Ilvessalo-Lax, H., Berglund, J., Lax, H-G., \& Mustonen, T. (2018). The Quark (pp. 63-98). In H. Tunón (Ed.). Nordic IPBES-like Assessment of Biodiversity and Ecosystem Services in Coastal Ecosystems. Case Areas. TemaNord 2018:532 Copenhagen: Nordic Council of Ministers.

Jacobsen, R. B. \& Raakjær, J. 2102. A Case of Greenlandic Fisheries Co-Politics: Power and Participation in Total Allowable Catch Policy-Making Hum Ecol (2012) 40:175-184. doi: 10.1007/s10745-012-9458-7

Jankkari, J. (2013). Arjen ja byrokratian rajapinnalla - kansalaispalaute vesienhoidon suunnittelussa. (Between bureaucracy and everyday life - public responses in the planning of river-basin management). The Finnish Environment 8/2013. http://hdl.handle.net/10138/40252

Kauppila, J. (2016). The legal effectiveness of the river basin management plan. Publications of the University of Eastern Finland, Dissertations in Social Sciences and Business Studies, no 138 .

Kvarnström, M. \& Boström, J. (2018). Kalix archipelago (pp. 29-6o). In H. Tunón (Ed.). Nordic IPBES-like Assessment of Biodiversity and Ecosystem Services in Coastal Ecosystems. Case Areas. TemaNord 2018:532 Copenhagen: Nordic Council of Ministers.

Mäenpää, M. Tolonen, S. (2011). Kooste vesienhoitoalveiden vesienhoito-suunnitelmista vuoteen 2015 (The summary of the River Basin District's River Basin Management Plans until 2015). The Finnish Environment 23/2011. http://hdl.handle.net/10138/37044.

Management Plan for Bothnian Bay Water District (2009). Förvaltningsplan för Bottenvikens vattendistrikt 2009-2015. Länsstyrelsens rapportserie 2010/2. Vattenmyndigheten i Bottenvikens vattendistrikt.

Miljömålsberedningen. (2013). Rapport från expertgruppen om en sammanhållen och hållbar vattenpolitik. 2013-09-27. Stockholm: Miljömålsberedningen.

Ministry of Environment and Food Denmark (2016). Planlovsaftale styrker vækst of udvikling i Danmark. http://em.dk/nyheder/2016/16-06-o9-aftale-om-planlov . 16-04-2017.

Ministry of Environment and Nature. (2014). The Fifth National Report to CBD. Government of Greenland.

Ministry of the Environment (2012). Vesienhoidon toimenpiteiden seurantajärjestelmä kaudelle 2010-2015 (Monitoring system for river basin management measures 2010-2015).

Environmental Administration Guidelines 1/2012.

http://www.ym.fi/download/noname/\%7B957E187E-6DE9-4CEE-A5F42D6C9426F1F2\%7D/37510

Ministry of the Environment. (2012). Vesienhoidon toimenpiteiden seurantajärjestelmä kaudelle 2010-2015 (Monitoring system for river basin management measures 2010-2015).

Environmental Administration Guidelines 1/2012. 
Mustonen, T. (2018a). Neiden/Näätämö (pp. 19-28). In H. Tunón (Ed.). Nordic IPBES-like Assessment of Biodiversity and Ecosystem Services in Coastal Ecosystems. Case Areas. TemaNord 2018:532 Copenhagen: Nordic Council of Ministers.

Mustonen, T. (2018b). Puruvesi (pp. 99-110). In H. Tunón (Ed.). Nordic IPBES-like Assessment of Biodiversity and Ecosystem Services in Coastal Ecosystems. Case Areas. TemaNord 2018:532 Copenhagen: Nordic Council of Ministers.

Newig, J. \& Koontz, T. (2014). Multi-level governance, policy implementation and participation: the EU's mandated participatory planning approach to implementing environmental policy. Journal of European Public Policy. 21:248-267.

Øresundsvandsamarbejdet (2014). Beskyt Øresunds natur? Bør der oprettes et marint reservat.

Pascual et al. (2017). Valuing nature's contributions to people: the IPBES approach. Current Opinion in Environmental Sustainability 2017, 26:7-16

Persson, Å. (2004). Environmental Policy Integration. An Introduction. Stockholm: Stockholm Environment Institute.

Petersen, A. H., Clausen, P., Gamfeldt, L., Hansen, J. L. S., Norling, P., Roth, E., Svedäng, H., \& Tunón, H. (2018). The Sound (pp. 133-166). In H. Tunón (Ed.). Nordic IPBES-like Assessment of Biodiversity and Ecosystem Services in Coastal Ecosystems. Case Areas. TemaNord 2018:532 Copenhagen: Nordic Council of Ministers.

Poulsen, M. K. (2018). Disko Bay (pp. 227-246). In H. Tunón (Ed.). Nordic IPBES-like Assessment of Biodiversity and Ecosystem Services in Coastal Ecosystems. Case Areas. TemaNord 2018:532 Copenhagen: Nordic Council of Ministers.

Rasmussen, R. O. (2003). Havfiskeri/kystfiskeri-magt og afmagt i Grønlands hovederhverv. In Winther, G. (ed.), Demokrati og magt i Grønland. Århus Universitetsforlag, Denmark, pp. 133161. Danish.

Schwerdtfeger, H. (1976). Atangmik. Påtvungne udviklingsproblemer i en grønlandsk bygd. Nyt fra samfundsvidenskaberne 38. J.J trykteknik A/S, Denmark. Danish. Sørensen (1976).

SEPA (2011). Synergimöjligheter, målkonflikter och problem i miljömålsarbetet. En analys utifrån nyckelaktörers perspektiv. Rapport 6474, December 2011. Swedish Environmental Protection Agency (SEPA).

SEPA handbook. (2006). Samverkan om vattenförvaltning-information, kommunikation och samråd. Handbok 2006:1. Swedish Environmental Protection Agency (SEPA).

SFS 2011:619. Förordning (2011:619) med instruktion för Havs- och Vattenmyndigheten. Miljöoch energidepartementet. Regeringskansliet. Svensk Författningssamling (SFS).

Söderberg, C. (2016). Complex governance structures and incoherent policies: implementing the water framework directive in Sweden. Journal of Environmental Management, 1(183), pp. 90-97.

Söderberg, C. and Eckerberg, K. (2013). Rising policy conflicts in Europe over bioenergy and forestry. Forest Policy and Economics (33), pp. 112-119.

Sørensen, J., Roto, J., \& Tunón, H. (2018). Faroe Islands (pp. 205-225). In H. Tunón (Ed.). Nordic IPBES-like Assessment of Biodiversity and Ecosystem Services in Coastal Ecosystems. Case Areas. TemaNord 2018:532 Copenhagen: Nordic Council of Ministers.

SOU 2002:105. Klart som vatten - Utredningen Svensk administrations betänkande angående införandet av EG:s ramdirektiv för vatten i Sverige. Statens offentliga utredningar. Stockholm: Fritzes.

SOU 2007:60. Bilaga B13. Dricksvattenförsörjning i förändrat klimat. Sårbarheter för klimatförändringar och extremväder, samt behov av anpassning och anpassningskostnader. Arbetsgruppen för dricksvatten. Underlagsrapport utarbetad för Klimat- och sårbarhetsutredningen, 2007-04-02. 
Svedäng, H. et al. (2018). Chapter 4: Drivers and indirect drivers of change in the context of different perspectives of human well-being (quality of life). In Belgrano. A., Ejdung, G., Lindblad, C., \& Tunón, H. (Eds.) Nordic IPBES-like Assessment of Biodiversity and Ecosystem Services in Coastal Ecosystems. Report. TemaNord 2018: Copenhagen: Nordic Council of Ministers.

SwAM. (2014). About us - Vision. Swedish Agency for Marine and Water Management

Swedish Water Authorities. (2013). PM till Miljömålsberedningen. Synpunkter från vattenmyndigheterna på "Rapport från expertgruppen om en sammanhållen och hållbar vattenpolitik". PM 2013-11-13. Vattenmyndigheterna.

Swedish Water Authorities. (2014a). Water Boards.

Swedish Water Authorities. (2014b). Participation and dialogue.

Swedish Water Authorities. (2014c). Beslutsdokument.

Swedish Water Authorities. (2015). Sammanställning av myndigheternas och kommunernas redovisning av genomförda åtgärder 2014. Vattenmyndigheterna i samverkan: Bottenhavets vattendistrikt. 2015-05-05.

Swedish Water Authorities. (2015a). Sammanställning av kommunernas och myndigheternas rapportering. Yearly reports on implementation of Programmes of Measures from 2010-2015: http://www.vattenmyndigheterna.se/Sv/nyheter/2015/Pages/rapportering-2014.aspx

Tunón, H. (Ed.). (2018). Nordic IPBES-like Assessment of Biodiversity and Ecosystem Services in Coastal Ecosystems. Case areas. TemaNord 2018: Copenhagen: Nordic Council of Ministers.

URL: http://www.vattenmyndigheterna.se/En/Pages/participation-and-dialogue.aspx

URL: http://www.vattenmyndigheterna.se/En/Pages/water-boards.aspx

URL: https://www.havochvatten.se/en/start/about-us/vision.html

URL:http://www.vattenmyndigheterna.se/Sv/omvattenmyndigheterna/beslutsdokument/Page s/default.aspx

Valve, H., Kauppila J., Kaljonen, M., Kauppila, P. (2014). Kohti hyvää ekologista tilaa:miten syntyy vesienhoitotoimenpide?. Ympäristöpolitiikan ja -oikeuden vuosikirja VII 2014, s. 371-376.

Vannportalen (2017). Available at: www.vannportalen.no

Vävare, S. \& Häggblom, M. (2018). Lumparn area (pp. 111-131). In H. Tunón (Ed.). Nordic IPBESlike Assessment of Biodiversity and Ecosystem Services in Coastal Ecosystems. Case Areas. TemaNord 2018:532 Copenhagen: Nordic Council of Ministers.

Wegeberg, S. \& Boertmann, D. (eds). (2016). Disko Island and Nuussuaq Peninsula, West Greenland. A strategic environmental impact assessment of petroleum exploration and exploitation. Scientific Report from DCE, Danish Centre for Environment and Energy, Aarhus University No. 199, 108 pp. http://dce2.au.dk/pub/SR199.pdf

Westberg, V. (ed.); Bonde, A., Haldin, L,, Koivisto, A-M., Mäensivu, M., Mäkinen, M., and Teppo, A. (2016). Together towards better status of water: River basin management plan for Kokemäenjoki-Archipelago Sea-Botinian Sea River Basin District for 2016-2021 (2015). Tillsammans för god vattenstatus: Förvaltningsplanen för Kumo älvs-SkärgårdshavetsBottenhavets vattenförvaltningsområde 2016-2021. Rapporter 102/2015. Närings-, trafik- och miljöcentralen i Södra Österbotten. http://urn.fi/URN:ISBN:978-925-314-341-8 



\section{Sammanfattning}

Rapporten beskriver biologisk mångfald och ekosystemtjänster i nordiska kustområden, en miljö som är gemensam för alla nordiska länder. Rapportens struktur följer delvis det ramverk för kunskapssammanställning som används av IPBES, den mellanstatliga plattformen för biologisk mångfald och ekosystemtjänster.

Den här studien baseras främst på kunskaps-sammanställning från tio fallstudier i kustområdena runt Danmark, Finland, Island, Norge och Sverige, samt från de autonoma områdena Färöarna, Grönland och Åland.

Syftet med kunskapssammanställningen är att beskriva status och trender för biologisk mångfald, ekosystem och ekosystemtjänster i kusten, samt att identifiera drivkrafter och belastningar som ger effekter för människor, samhälle och förvaltning. Sammanställningen baseras på litteratur från naturvetenskapliga och samhällsvetenskapliga studier. Den kan ge stöd till beslutsfattare och politiker i Norden för att samverka till en hållbar utveckling av kustområden.

De nordiska kustområdena varierar på många sätt, som klimat och geomorfologi med arktiska förhållanden på Grönland, den norska kustens kelpskogar och branta fågelberg samt skärgårdar och flacka kustområden i Östersjön. Kustvattnets karaktär, från Nordsjökustens höga salthalt till de sötvattensliknande förhållandena i Bottenviken, styr utbredningen av växter och djur. Människans påverkan på kustzonen varierar i de olika områdena, där kustvattnets ekologiska status i nordost Atlanten är god, men i egentliga Östersjön och Finska viken bedöms vattenkvaliteten som måttlig. Populationerna för exempelvis säl och havsörn har ökat under de senaste decennierna efter att användning av miljögifter som PCB och DDT förbjudits. Däremot finns i dag negativa trender för andra arter, som exempelvis den kraftiga minskningen av ejderpopulationen i Östersjön.

Nordens kustområden påverkas av en mängd miljöfaktorer, som klimatförändring, effekter av nya kemiska ämnen, övergödning och mikroplaster samt invasiva främmande arter.

Gemensamt för de flesta av Nordens kustområden är det ökande exploateringstryck som en följd av samhällsutveckling och befolkningsökning i vissa områden. Det finns därför behov av att ytterligare utveckla förvaltningssystem som minskar risken för negativ påverkan på ekosystem och som tar hänsyn till naturområdenas bidrag till människans välbefinnande. Det behövs ett fortsatt arbete med förvaltning av det kustnära fisket samt förbättrade instrument för lokal och regional planering för att motverka negativa effekter på kustområdena. Det är viktigt att inkludera lokalbefolkningen i början av detaljplaneringen och i den fortsatta förvaltningsprocessen av kust- och skärgårdsmiljöerna. Kustmiljöer samt enstaka arter har även en stor kulturell roll för människor och påverkar livskvaliteten. 
Studien pekar på de nordiska kustområdenas olika miljöförhållanden liksom på gemensamma faktorer, som befolkningens intresse för natur och miljö samt ländernas likvärdiga sociala och politiska styrmedel. Detta visar att det nordiska samarbetet har stor betydelse för en hållbar förvaltning av kustområden och bör stärkas i det framtida arbetet. 
Biodiversity and ecosystem services in Nordic coastal ecosystems: an IPBES-like assessment. Volume 1. The general overview

Belgrano, A

Clausen, $\mathrm{P}$

Ejdung, G

Gamfeldt, L

Show others and affiliations

Responsible organisation

Nordic Council of Ministers, Nordic Council of Ministers Secretariat

2018 (English)

Book (Other academic)

\section{Abstract [en]}

This report describes the status and trends of biodiversity and ecosystem services in the Nordic region, the drivers and pressures affecting them, interactions and effects on people and society, and options for governance. The main report consists of two volumes. Volume 1 The general overview (this report) and Volume 2 The geographical case studies. This study has been inspired by the Intergovernmental Science-Policy Platform on Biodiversity and Ecosystems Services (IPBES). It departs from case studies (Volume 2, the geographical case studies) from ten geographical areas in the Nordic countries (Denmark, Finland, Iceland, Norway, Sweden) and the autonomous areas of Faroe Islands, Greenland, and Aland. The aim was to describe status and trends of biodiversity and ecosystem services in the Nordic region, including the drivers and pressures affecting these ecosystems, the effects on people and society and options for governance. The Nordic study is structured as closely as possible to the framework for the regional assessments currently being finalized within IPBES. The report highlights environmental differences and similarities in the Nordic coastal areas, like the inhabitants' relation to nature and the environment as well as similarities in social and policy instruments between the Nordic countries. This study provides background material for decision-making and it is shown that Nordic cooperation is of great importance for sustainable coastal management and should be strengthened in future work.

Place, publisher, year, edition, pages

Copenhagen: Nordisk Ministerråd, 2018. , p. 200

Series

TemaNord, ISSN 0908-6692; 2018:536

National Category

Environmental Management

Research subject

Animal life; Environment; Climate; Marine environment; Economy; Fisheries; Food; Welfare; Arctic; Barents Region; Baltic Sea Region; European Union; The Baltic Region

\section{Identifiers}

URN: urn:nbn:se:norden:org:diva-5272

DOI: $10.6027 /$ TN2018-536

ISBN: $978-92-893-5664-0$ (print)

ISBN: 978-92-893-5665-7 (electronic)

ISBN: 978-92-893-5666-4 (electronic)

OAI: oai:DiVA.org:norden-5272

DiVA, id: diva2:1219782

Available from: 2018-06-18 Created: 2018-06-17 Last updated: 2018-06-18 
(11) Nordic Council of Ministers

Biodiversity and ecosystem services in Nordic coastal ecosystems: an IPBES-like assessment

\section{Volume 1}

The general overview 


\section{Biodiversity and ecosystem services in Nordic coastal ecosystems: an IPBES-like assessment. Volume 1. The general overview}

Belgrano, A. (Ed.)

Belgrano, A., Clausen, P., Ejdung, G., Gamfeldt, L., Gundersen, H., Hammer, M., Hancke, K., Hansen, J.L.S., Heiskanen, A-S., Häggblom, M., Højgård Petersen A., Ilvessalo-Lax, H., Jernberg, S., Kvarnström, M., Lax, H-G., Køie Poulsen, M., Lindblad, C., Magnussen, K., Mustonen, T., Mäenpää, M., Norling, P., Roth, E., Roto, J., Sogn Andersen, G., Svedäng, H., Söderberg, C., Sørensen J., Tunón, H., Vihervaara, $P .$, Vävare, $S$. 
Biodiversity and ecosystem services in Nordic coastal ecosystems: an IPBES-like assessment. Volume 1. The general overview

Belgrano, A. (Ed.)

Belgrano, A., Clausen, P., Ejdung, G., Gamfeldt, L., Gundersen, H., Hammer, M., Hancke, K., Hansen, .L.S., Heiskanen, A-S., Häggblom, M., Højgård Petersen A., Ilvessalo-Lax, H., Jernberg, S., Kvarnström, M., Lax, H-G., Køie Poulsen, M., Lindblad, C., Magnussen, K., Mustonen, T., Mäenpää, M., Norling, P., Roth, E., Roto, J., Sogn Andersen, G., Svedäng, H., Söderberg, C., Sørensen J., Tunón, H., Vihervaara, P., Vävare, S.

Project-leader: Gunilla Ejdung and Britta Skagerfält.

ISBN 978-92-893-5664-0 (PRINT)

ISBN 978-92-893-5665-7 (PDF)

ISBN 978-92-893-5666-4 (EPUB)

http://dx.doi.org/10.6027/ANP2018-536

TemaNord 2018:536

ISSN 0908-6692

Standard: PDF/UA-1

ISO 14289-1

(c) Nordic Council of Ministers 2018

Cover photo: Kasper Hancke

Print: Rosendahls

Printed in Denmark

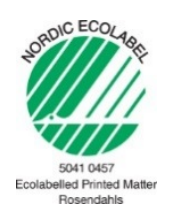

Disclaimer

This publication was funded by the Nordic Council of Ministers. However, the content does not necessarily reflect the Nordic Council of Ministers' views, opinions, attitudes or recommendations.

Rights and permissions

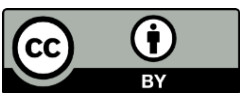

This work is made available under the Creative Commons Attribution 4.0 International license (CC BY 4.0) https://creativecommons.org/licenses/by/4.0

Translations: If you translate this work, please include the following disclaimer: This translation was not produced by the Nordic Council of Ministers and should not be construed as official. The Nordic Council of Ministers cannot be held responsible for the translation or any errors in it. 


\section{Contents}

Foreword

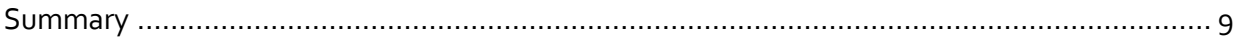

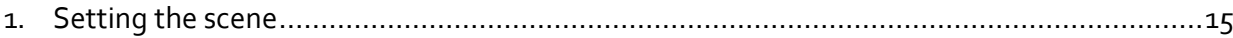

1.1 Context of the Nordic coastal zone assessment ............................................

1.2 Previous assessments and the conceptual "IPBES" framework ..............................17

1.3 The Nordic model for ecosystem assessment ..................................................19

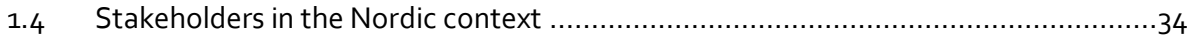

1.5 Introduction to Nordic case studies where the IPBES approach is tested ..................34

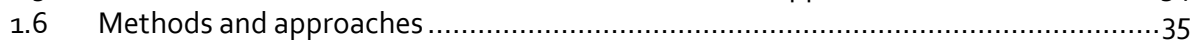

1.7 The structure of the Nordic assessment and the core questions............................... 39

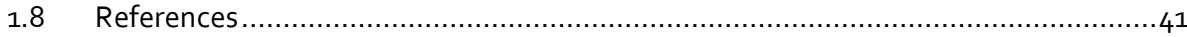

2. Nature's Contributions to People and Human Well-being in a Nordic coastal context ........ 45

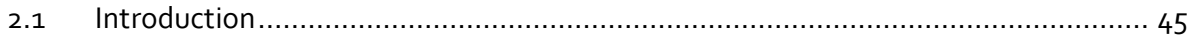

2.2 Relationships and impacts of changes regarding nature's contributions to people .. 48

2.3 Identifying aspects of biodiversity and ecosystem services critical to social relationships, spirituality and cultural identity ........................................... 54

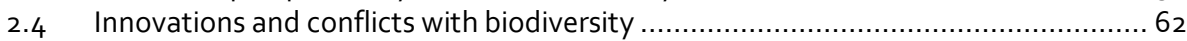

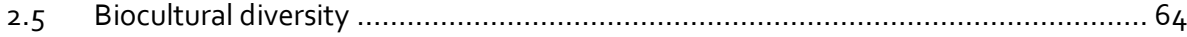

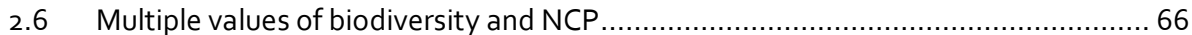

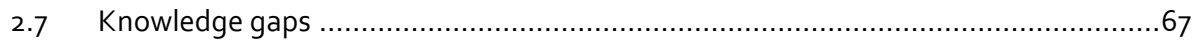

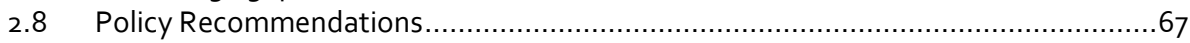

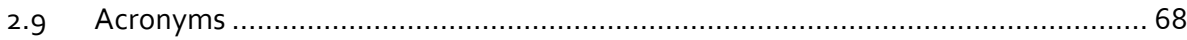

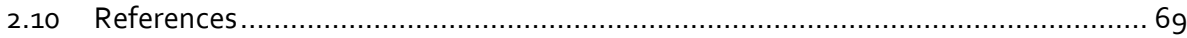

3. Status and Trends of Biodiversity and Ecosystem Function ....................................... 75

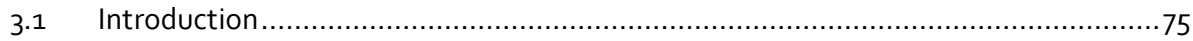

3.2 Defining biodiversity and its importance to Nordic marine life .............................. 77

3.3 Defining Ecosystem function and value to human societies in Nordic countries .......78

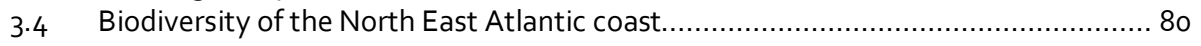

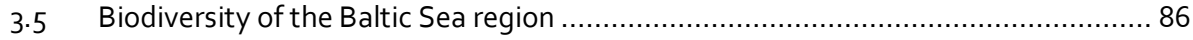

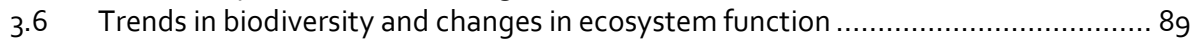

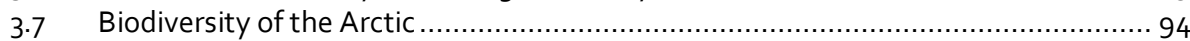

3.8 Differences and similarities between regions ................................................. 96

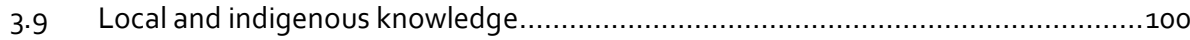

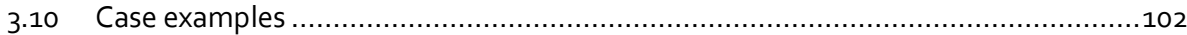

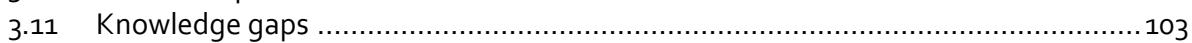

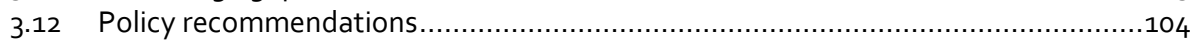

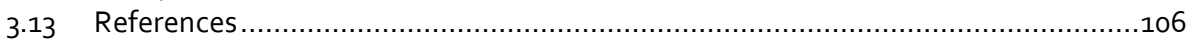

4. Direct and indirect drivers of change indifferent perspectives of human well-being (quality of life)

Introduction .

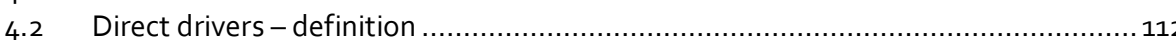

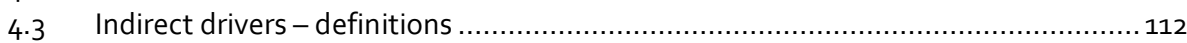

4.4 Past and current trends of direct and indirect drivers of change - a Nordic

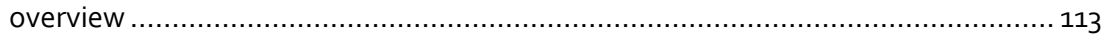

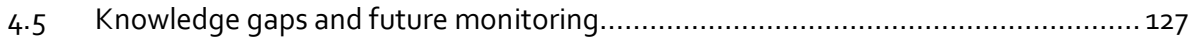

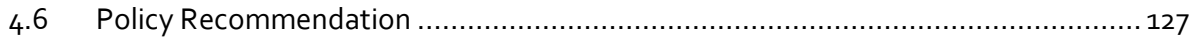

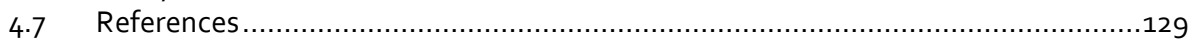


5. Analysis of interactions between Biodiversity (B), Ecosystem Services (ES), and Nature's Contributions to People (NCP) ................................................................133

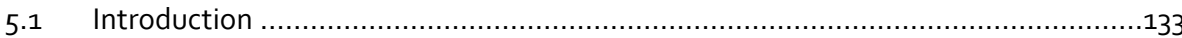

5.2 Qualitative comparative analysis based on expert judgements.......................... 134

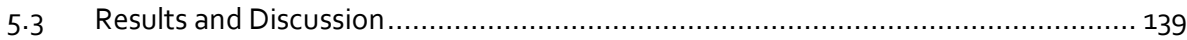

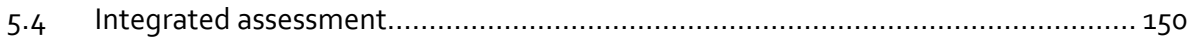

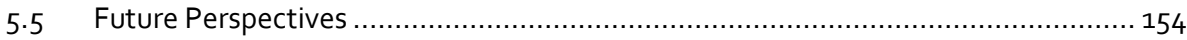

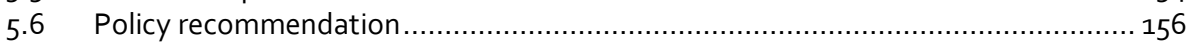

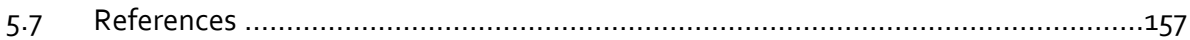

6. Options for governance, institutional arrangements and private and public decision-

making across scales and sectors................................................................... 161

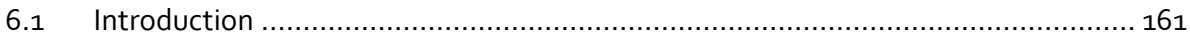

6.2 Framing institutions and policy options for biodiversity and ecosystems governance ....................................................................................... 162

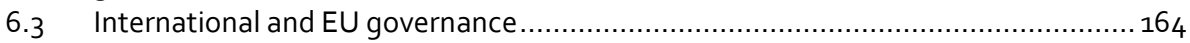

6.4 Formal institutional framework for Nordic governance - comparing WFD implementation in the Nordic region ........................................................ 167

6.5 Mainstreaming biodiversity and ecosystem services across sectors in the Nordic region: Examples from water governance and the case studies ..........................171

6.6 Opportunities and challenges for policy and decision-making ......................... 181

6.7 Detected uncertainties and options for the future ........................................ 183

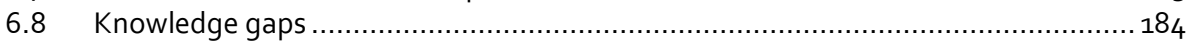

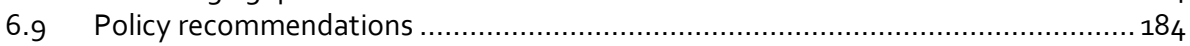

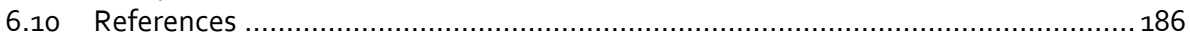

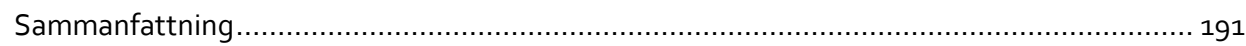

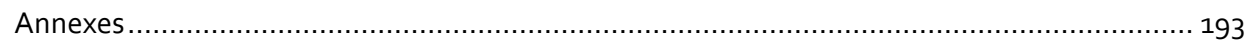

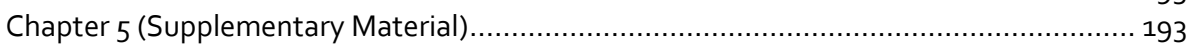

Annex C - List of editors, co-chairs, authors and reviewers ....................................... 193

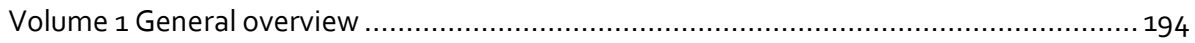




\section{Summary}

This study has been inspired by the Intergovernmental Science-Policy Platform on Biodiversity and Ecosystems Services (IPBES). The aim of the assessment was to describe the status and trends of biodiversity and ecosystems in the Nordic region, including the drivers and pressures affecting these ecosystem components, as well as the effects on people and society and options for governance. Ultimately, this study provided an opportunity to aid the process of utilizing scientific results in the policy and decision-making realm, thus forwarding the science-policy interphase. The Nordic study is structured as closely as possible to the framework for the regional assessments currently being finalized within IPBES. This assessment has been based on information provided by the following case study areas in the Nordic countries: Näätämö/ Neiden basin, Kalix Archipelago, Kvarken/the Quark, Puruvesi Lake in North Karelia, the Lumparn area, Öresund, Helgeland coast, Faroe Islands (Føroyar), Broddanes West Fjords and the coastal areas of Húsavík (Iceland) and Disko Bay (Greenland).

The objectives of the assessment were to address the following questions:

- What are the main drivers and pressures affecting biodiversity, ecosystem services and ecosystem function?

- How does global, regional and national policy influence biodiversity, ecosystem services and human well-being in the Nordic region? What opportunities exist in policy-making?

- How can we better integrate indigenous and local knowledge (ILK) perspectives on biodiversity, ecosystem services and nature's contributions to people (NCP) in decision-making? How can we apply their culture and traditional management methods to support decision-making?

- What opportunities exist for sustainability and nature-dependent human wellbeing in Nordic societies?

- What biodiversity and ecosystem values define NCP in the Nordic coastal region?

- How can data sources such as Earth Observation and GIS spatial data be used in assessments to support decision-making?

- What are the major gaps in data, knowledge, management and decision-making systems? How can these gaps be minimized? 
The outcomes from the assessment has been summarized in the following key messages:

- A. The Nordic coastal region has many natural assets and provides numerous ecosystem services:

- A1. The Nordic coastal region is unique due to the variability in nature types and biodiversity. Its coastal areas support examples of many different habitats spanning the temperate to the Arctic zone. This diversity supports considerable biodiversity that people depend on for their livelihoods;

- A2. The Nordic coastal region contains several globally important species and habitats. These include the wintering bird assemblages in the shallow seas around Denmark, the unique habitats of the Baltic Sea (the largest brackish water area in the world), the kelp forests and breeding seabird colonies on offshore islands and cliffs in northern regions along the Norwegian coast, the recovering populations of whales in the North Atlantic Ocean, the assemblages of Arctic species and the recovering stocks of cod and other species in the North Sea and further north;

- A3. Most of the region's biological value is in the form of large concentrations of fairly common species. The region houses habitats and assemblages of species that are typical of temperate seas warmed by the Gulf Stream, along with the Arctic and the Baltic Seas, parts of which are seasonally frozen. The strong seasonality also results in long and short distance migration of many fish, birds and mammals using the coastal and marine systems in the region. These include globally important winter concentrations of migrant seabirds and shorebirds in the southern part of the region and similarly important summer concentrations in the northern and Arctic regions;

- A4. The ecological status in the North East Atlantic and Bothnian Sea is good. The status is moderate in the Arkona Basin and the Sound, but poor in the Baltic Proper and Gulf of Finland;

- A5. Many biological values of the region are slowly recovering from very low values following past overexploitation. These biological values include populations of fish-eating sea birds and white-tailed eagle, grey heron, crane and several geese species in the Baltic Sea. It also includes cod, herring, mackerel, ringed seal, grey seal, harbor seal, hooded seal, North Atlantic fin whale and bowhead whale along the Norwegian coast, along with wintering and breeding populations of geese and swans in Danish coastal areas. In the Baltic Sea, and particularly in the Bothnian Bay, there is a slow recovery from DDT and PCB pollution events. However, pollution from heavy metals and contamination from persistent toxic chemical and radiation events remains a challenge;

- A6. The network of marine and coastal protected areas is important for preserving biodiversity and ecosystem services in the Nordic region. Regulations to accomplish sustainable use of these areas are under development; 
- A7. The coastal natural resources in the region have provided food for people living in the Nordic region for thousands of years. They continue to provide this today, especially from fisheries in the shallow seas, but also from animals feeding on the coastal habitats and birds breeding on the coastal cliffs. These resources are under various management regimes; some traditional going back at least hundreds of years and others with a more recent natural science basis;

- A8. The diversity of Nordic coastal and marine ecosystems continues to deliver goods and services that are vital to the livelihoods of many people in the region. Beaches and other coastal areas are important leisure resources for tourists from other countries. Particularly holidaymakers and weekend visitors from within the Nordic countries frequent the southern parts of the region. There are also continuing traditions and systems of using coastal and marine resources across the Nordic region. These are integrated into the modern lives of people living both in the rural areas and, increasingly, in cities throughout the region;

- Ag. The Nordic coastal regions support communities with strong traditional ties to nature, which provides opportunities for resource management based on traditional use, management and governance regimes. These communities include both Inuit/ Greenlandic and Saami peoples in the north, coastal communities along the seaboard of Norway, Sweden, Finland and Denmark, as well as populations in the Faroe Islands and Iceland;

- A10. The coastal natural resources of the region provide inspiration for the people living in the Nordic countries. Some are strongly embedded in cultural identities and ways of living. These cultural values provide a powerful bond between people and nature and are a major reason for the persistence, and in some cases recovery, of natural resources in these coastal regions.

- B. The coastal Nordic region is under pressure:

- B1. Some species are still in decline in the region despite conservation actions aiming to assist their recovery. This includes the globally important populations of breeding auks (puffin, razorbill, common guillemot, Brünnich's guillemot) and some breeding seabirds (e.g. kittiwake). There has been a considerable decline in sea grass meadows, kelp forests and fucoid algae/or brown seaweeds in different parts of the region. Due to population crashes in the past century, species like sturgeon and lamprey in the Baltic Sea remain at very low populations;

- B2. The Arctic - also the parts within the Nordic region - is the part of the planet most heavily affected by climate change and is warming at a far higher rate than any other region on earth. This is having and will continue to have dramatic impacts on ecosystems and their services, including through ocean acidification. Throughout the region, there are emerging impacts of climate change. Northern species of birds, fish and bivalves cease to breed in southern countries like Denmark, migrating northward and expanding their 
breeding grounds along the coasts of Norway, Sweden and Finland. Fish e.g. mackerel, herring and tuna, are moving to more northern waters around Iceland and Greenland. There are changes in the coastal food web, potentially impacting food sources for some of the largest marine creatures in the region, e.g. humpback whale. Ocean warming is having negative impacts on the extensive kelp forests in the western oceans off Norway;

- B3. Chemical pollutants, eutrophication and plastics are affecting the coastal waters of the region. The historical heavy industrial and nuclear radiation pollution is still affecting parts of the Baltic Sea. The situation has greatly improved over the past 30 years. In other parts of the region, there is considerable run-off of agricultural fertilizers and pesticides, although the amount has been reduced from past levels. Eutrophication of the coastal waters remains a problem, evidenced by impacts to species composition in many areas. In recent years, fears have emerged on what consequences the high quantities of plastics and nanoparticles in the oceans may lead to. It will take many centuries for these particles to degrade in the regions' colder northern waters, and their impact on marine life is negative;

- B4. Invasive species pose serious challenges to parts of the Nordic coastal ecosystems. Significant challenges arise from the Japanese rose (Rosa rugosa) on coastal foreshores and sand dune areas in Denmark and southern Sweden. Challenges also arise as a result of a variety of invasive marine animals and plants, including the round goby in the Baltic Sea and in the North Sea, and king crab in the Bering Sea. Measures against alien invasive species may mitigate the effects of these species. Such measures may include the implementation of legislation and/or physical measures to remove already established species;

- B5. Infrastructure development in marine and coastal areas poses challenges. The Nordic region is a global frontrunner in near- and offshore wind turbine technological development and installation. However, wind power plants have impacts on e.g. migratory birds and bats. In addition, there are impacts associated with the construction of the large bridges between Denmark and Sweden, and Denmark and Germany. The trend to set aside coastal or nearcoastal areas for building summer cottages brings challenges of reduced access, increased disturbance and the need for water treatment. There is oil and gas exploration and mining industry in the northern seas that has potential to impact these areas. Of particular concern is the slow break-down of pollutants in cold waters of low biological capacity.

- C. Building resilient futures in the Nordic coastal region:

- C1. The political and governance systems of the Nordic region are transparent and fair. There is a broad interest within the Nordic countries to pursue development pathways to reduce local and global impacts on natural resources. There is good access to coastal areas and strong emphasis on the use of nature and natural areas for livelihoods and recreation. These values 
and traditions need to be maintained to continue to provide space for nature and to allow people to benefit from natural coastal areas. Nordic countries are able to implement and maintain systems for improved coastal management and sustainable harvesting of species, habitats and resources;

- C2. There are good examples of indigenous and local peoples participating in coastal nature management in the northern regions. This is critically important for continued subsistence use and for maintaining ecosystem services in the north. Better integration and support of indigenous and local knowledge within conservation management and in governance of resource use in the region would be beneficial;

- C3. Ongoing progress to clean up pollution and reduce eutrophication in rivers, lakes, coastal areas and open seas needs to be continued. This relates to all the countries in the Nordic region and is equally important on national, regional and international scales. This can be achieved through catchment-based management approaches, as eutrophication is mainly caused by run-off from land. There have been intensive efforts to reduce the secondary environmental impacts from the large marine aquaculture industries (e.g. salmon farmed in the Norwegian fjords), shell fish farming (e.g. blue mussels on poles and other structures in Danish and Swedish seas), along with the emerging seaweed farming industries;

- C4. Some fish stocks and populations of marine mammals are recovering in the region. Further recovery can be accomplished through careful review and changes to policies as required. However, some populations (e.g. seals) have recovered to the point where they are causing problems. For those fisheries and populations of marine mammals that are still in decline, further efforts are required to help return populations to a healthy state;

- $C_{5}$. Cooperation among the Nordic countries is needed to improve coastal zone planning and management. Policies and their implementation need to balance the needs of the natural system and human development in coastal areas (e.g. summer houses, urban areas, industry). Examples can be drawn from ongoing marine spatial planning initiatives;

- C6. Coastal resilience to rising seas needs to be enhanced, e.g. through naturebased solutions offered by natural or moderately modified ecosystems. Changes in the coastal regions may be dramatic in the future due to climate change and related sea level rise, flooding, extreme weather events and increased run off from inland water bodies and melting ice;

- C7. The legal frameworks in most Nordic countries have national laws, EU directives and regulations and follow regional marine conventions including HELCOM and OSPAR. These are often developed from agreed targets of international non-binding agreements, such as those under the Convention on Biological Diversity and the United Nations Framework Convention on Climate Change. This legislative framework is strong, but can always be 
further developed to enhance the outcomes for nature and people in the coastal regions.

The following options for policy makers have been proposed:

- Evaluate the costs and benefits of existing environmental policies, prioritise and streamline them to help overcome the high density of policies;

- Where possible, coordinate the implementation of policies across the Nordic region to reduce policy conflicts;

- Identify and adjust policies that counteract incentives for conservation and the sustainable use of biodiversity in coastal areas;

- Increase political focus on the status of marine biodiversity and the influence of human activities on species and habitat diversity. This is closely related to work with the UN Sustainable Development Goals (SDGs);

- Involve science-based assessments and priorities in policymaking in terms of identifying most needed conservation and management policy initiatives;

- Safeguard the right to public access of coastal areas as access to nature maintains access to a number of non-material nature's contributions to people, such as identity, physical and psychological experiences, knowledge and inspiration, as well as material benefits such as food and ornaments. This collectively helps maintain society's sense of duty to protect the environment;

- Implement ecosystem-based adaptation to increase the coastal region's resilience to climate change;

- Draw benefits from technological developments that reduce the region's ecological footprint; and

- Identify pathways to achieve the 2050 vision of the Strategic Plan for Biodiversity and implement the Sustainable Development Goals and their targets. 
Nordic Council of Ministers

Nordens Hus

Ved Stranden 18

DK-1061 Copenhagen K

www.norden.org

\section{Biodiversity and ecosystem services in Nordic coastal ecosystems: an IPBES-like assessment Volume 1. The general overview}

This report describes the status and trends of biodiversity and ecosystem services in the Nordic region, the drivers and pressures affecting them, interactions and effects on people and society, and options for governance. The main report consists of two volumes. Volume 1 The general overview (this report) and Volume 2 The geographical case studies. This study has been inspired by the Intergovernmental Science-Policy Platform on Biodiversity and Ecosystems Services (IPBES). It departs from case studies (Volume 2, the geographical case studies) from ten geographical areas in the Nordic countries (Denmark, Finland, Iceland, Norway, Sweden) and the autonomous areas of Faroe Islands, Greenland, and Åland. The aim was to describe status and trends of biodiversity and ecosystem services in the Nordic region, including the drivers and pressures affecting these ecosystems, the effects on people and society and options for governance. The Nordic study is structured as closely as possible to the framework for the regional assessments currently being finalized within IPBES. The report highlights environmental differences and similarities in the Nordic coastal areas, like the inhabitants' relation to nature and the environment as well as similarities in social and policy instruments between the Nordic countries. This study provides background material for decision-making and it is shown that Nordic cooperation is of great importance for sustainable coastal management and should be strengthened in future work. 